\title{
1 Seasonal Net Ecosystem Metabolism of the Near-Shore Reef System in La
}

2 Parguera, Puerto Rico

3 Melissa Meléndez ${ }^{1}$

4 Joseph Salisbury ${ }^{1}$

5 Dwight Gledhill ${ }^{2}$

6 Chris Langdon ${ }^{3}$

7 Julio M. Morel1 1,5

8 Derek Manzello ${ }^{6}$

9 Sylvia Musielewicz ${ }^{7,8}$

10 Adrienne Sutton ${ }^{7}$

Affiliation and address

$13{ }^{1}$ Department of Earth Sciences and Ocean Processes Analysis Laboratory, University of New Hampshire, Durham, 14 New Hampshire, 03824, USA

$15{ }^{2}$ National Oceanic and Atmospheric Administration (NOAA), Ocean Acidification Program, Silver Spring, 16 Maryland, 20910, USA

$17{ }^{3}$ Rosenstiel School of Marine and Atmospheric Science, University of Miami, Miami, FL, USA

$18 \quad{ }^{4}$ Department of Marine Sciences, University of Puerto Rico, Mayagüez, Puerto Rico, 00680, USA

$19{ }^{5}$ Caribbean Coastal Ocean Observing System, NOAA, Magueyes Island, Lajas, Puerto Rico, 00667, USA

$20{ }^{6}$ Atlantic Oceanographic and Meteorological Laboratory, NOAA, Miami, Florida, USA

$21{ }^{7}$ Pacific Marine Environmental Laboratory, NOAA, Seattle, Washington, 98115, USA

$22{ }^{8}$ University of Washington Joint Institute for the Study of the Atmosphere and Ocean, Seattle, WA 98195, USA

24 Correspondence to: Melissa Meléndez (mm19@wildcats.unh.edu)

26 Keywords: Puerto Rico, Coral Reef, Net Ecosystem Calcification, Net Ecosystem Production, 27 Dissolution, Carbonate Chemistry 


\section{Abstract}

34 Changes in ocean chemistry as a direct response to rising atmospheric carbon dioxide $\left(\mathrm{CO}_{2}\right)$ concentrations is causing a reduction of $\mathrm{pH}$ in the surface ocean. While the dynamics and trends in carbonate chemistry are reasonably constrained for open ocean waters, the ways in which ocean acidification (OA) manifests within the shallow near-shore waters, where coral reefs reside, is less understood. Constraining near-reef variability in carbonate chemistry and net ecosystem metabolic processes across diel, seasonal, and annual scales is important in evaluating potential biogeochemical thresholds of OA that could result in ecological community changes. The OA Test-Bed at La Parguera Marine Reserve in Puerto Rico provides long-term carbonate chemistry observations at high-temporal resolution within a Caribbean near-shore coral reef ecosystem. A 1-D model was developed using the carbon mass balance approach to yield information about net ecosystem production and calcification processes occurring in the water column adjacent to the reef. We present results of nine years of sustained monitoring at the Enrique mid-shelf forereef, which provides for the characterization of temporal dynamics in carbonate chemistry and net ecosystem metabolic processes encompassing near-shore and upstream locations. Results indicate that net heterotrophy and net dissolution dominate over most of the year, while net autotrophic conditions coupled with calcification dominated from only January to midApril. The average carbonate dissolution rate observed during summer is estimated at $-2.19 \mathrm{~g} \mathrm{CaCO}_{3} \mathrm{~m}^{-}$ 2 day $^{-1}$ and net community dissolution persists $76 \%$ of the seasonal year despite the water column remaining super-saturated with respect to aragonite. This corresponds to $-0.62 \mathrm{~kg} \mathrm{CaCO}_{3} \mathrm{~m}^{-2} \mathrm{year}^{-1}$, classifying the Enrique fore-reef and off-reef areas in a net dissolutional state. The combination of thermodynamically-driven depressed aragonite saturation state and high rates of respiration during the summer cause conditions that jeopardize the most soluble carbonate minerals and the free energy in the system for calcification. These data suggest that the reef area and associated ecosystems upstream of the sampling location are experiencing a net loss of $\mathrm{CaCO}_{3}$, possibly compromising coral ecosystem health and reef accretion processes necessary for maintenance as sea level increases. Resiliency from other climate-scale stressors including rising sea surface temperatures and coral bleaching is likely to be compromised in a system exhibiting net carbonate loss. 


\section{Introduction}

61 Oceans are the largest natural sink for excess atmospheric carbon dioxide $\left(\mathrm{CO}_{2, \text { air }}\right)$, currently absorbing 62 approximately one-third ( $28 \%$ ) of all anthropogenic $\mathrm{CO}_{2 \text {,air }}$ each year (Sabine et al., 2004; Le Quéré et 63 al., 2016). Under $\mathrm{CO}_{2}$ "baseline scenarios" of the Intergovernmental Panel on Climate Change (IPCC) 64 Representative Concentration Pathways (RCP6.0 and RCP8.5), dissolved $\mathrm{CO}_{2}$ in the surface ocean $65\left(\mathrm{CO}_{2, \mathrm{sw}}\right)$ will likely double over its pre-industrial concentration $(\sim 280 \mu \mathrm{atm})$ by the middle of this century, 66 producing significant changes in the ocean carbonate chemistry (IPCC, 2014).

As $\mathrm{CO}_{2 \text {,air }}$ is absorbed by the surface ocean it reacts to form carbonic acid $\left(\mathrm{H}_{2} \mathrm{CO}_{3}\right)$ which rapidly dissociates to hydrogen ion $\left(\mathrm{H}^{+}\right)$and bicarbonate ion $\left(\mathrm{HCO}_{3}^{-}\right)$, thereby lowering $\mathrm{pH}$ and hence the term "acidification". The resulting change in $\mathrm{pH}$ is buffered in part by the reaction of $\mathrm{H}^{+}$with carbonate ions $\left(\mathrm{CO}_{3}{ }^{2-}\right)$ forming bicarbonate. The low $\mathrm{pH}$ favors bicarbonate over carbonate thereby driving a net depletion of carbonate ions, as given by:

$$
\mathrm{CO}_{2, \text { air }} \leftrightarrow \mathrm{CO}_{2, s w}+\mathrm{H}_{2} \mathrm{O} \leftrightarrow \underbrace{\mathrm{H}_{2} \mathrm{CO}_{3}}_{\text {Carbonic Acid }} \leftrightarrow \mathrm{H}^{+}+\underbrace{\mathrm{HCO}_{3}^{-}}_{\text {Bicarbonate }} \leftrightarrow 2 \mathrm{H}^{+}+\underbrace{\mathrm{CO}_{3}^{2-}}_{\text {Carbonate }}
$$

76 This chemical process affects the degree to which seawater is saturated with respect to calcium carbonate $77\left(\mathrm{CaCO}_{3}\right)$ minerals:

$\mathrm{Ca}^{2+}+\mathrm{CO}_{3}^{2-} \leftrightarrow \mathrm{CaCO}_{3, \text { solid }}$

81 where, $\mathrm{Ca}^{2+}$ is the calcium ion. The solubility of $\mathrm{CaCO}_{3}$ minerals in seawater is described by Mucci 82 (1983) and is defined according to the stoichiometric solubility product constant ( $\mathrm{K}_{\mathrm{SP}}$ ) as a function of 83 temperature, pressure, and solution composition. The degree of carbonate saturation with respect to the $84 \mathrm{CaCO}_{3}$ mineral phase of interest (e.g., calcite, aragonite, Mg-calcite) is indicated by the saturation state $85(\Omega)$. Aragonite and calcite represent the most important calcium carbonate polymorphs, but Mg-calcite 86 can contain variable amounts of magnesium ion $\left(\mathrm{Mg}^{2+}\right)$ ranging from 10 to $>30 \%$ (Morse et al., 2007). 
87 The $\Omega$ is defined as the ratio of concentration product to $\mathrm{K}^{*}{ }_{\mathrm{SP}}$ :

$\Omega_{x}=\frac{\left[\mathrm{Ca}^{2+}\right]\left[\mathrm{Mg}^{2+}\right]\left[\mathrm{CO}_{3}^{2-}\right]}{K_{s p}^{*}}$

where, [ ] indicates total concentrations. Values of $\Omega>1$ are typical for tropical surface ocean waters and indicate that precipitation of the mineral phase is favored; if $\Omega<1$ dissolution is favored; and if $\Omega=1$ the mineral is in equilibrium with seawater and no net dissolution nor precipitation is expected. The energy available in the system to drive mineral precipitation can be related to $\Omega$ according to:

where, $\Delta G$ is the Gibbs free energy (cal mol-1 $\left.\mathrm{CaCO}_{3}\right), R$ is the ideal gas constant $\left(\mathrm{J} \mathrm{mol}^{-1} \mathrm{~K}^{-1}\right), T$ is absolute temperature $(\mathrm{K}), I A P$ is the ion activity product, and $k$ is the thermodynamic solubility product. The subscript $x$ denotes the mineral phase of interest. While regions of the Southern Ocean surface waters could experience under-saturation with respect to aragonite (i.e., $\Omega_{\text {arag }}<1$ ), should $\mathrm{CO}_{2 \text {,air }}$ levels exceed $500 \mu \mathrm{atm}$, tropical surface oceanic waters are projected to remain supersaturated (i.e., $\Omega_{\mathrm{arag}}>1$ ) for several centuries (Cao and Caldeira, 2008). Despite this continued super-saturation, concerns remain regarding the energy required by calcifers to sustain calcification and the free energy available in the system to drive mineral precipitation with continued OA (Cohen and Holcomb, 2009).

Multiple laboratory studies have reported reduced rates of calcification for many species of reef-building coral as a function of changes in carbonate chemistry and $\Omega_{\text {arag }}$ (e.g., Borowitzka 1981; Gao et al., 1993; Gattuso et al., 1998; Langdon et al., 2000, 2003; Leclercq et al., 2000, 2002; Marubini et al., 2001; Marshall and Clode, 2002; Ohde and Hossain, 2004; Langdon and Atkinson, 2005; Anthony et al., 2008;

111 Chan and Connolly, 2013). The rates of calcification (carbonate production) respond negatively, while 112 biologically-mediated and metabolic dissolution respond positively to declining $\Omega_{\text {arag }}$, representing not a 113 "switch" (i.e., threshold effect) response, but rather a "dimmer" effect (Andersson and Gledhill, 2013). 
114 Experimental studies have also revealed that $\Omega_{\text {arag }}$ has an indirect effect on coral recruitment by disrupting 115 larval-algal settlement interactions (Doropoulos et al., 2012) and direct effects on recruitment (Albright 116 et al., 2010) which could prove far more disruptive under the combination of warming and elevated 117 seawater $\mathrm{CO}_{2}$ than under either stressor singly (Albright and Mason, 2013).

119 These changes will have implications for shallow water $\mathrm{CaCO}_{3}$ mineral kinetics (Morse and Mackenzie, 120 1990), sediment shelf compositions, and potentially, marine ecosystems dependent upon skeletal and shell 121 structures comprised of $\mathrm{CaCO}_{3}$ minerals (Kleypas et al., 1999; Riebesell et al., 2000). The net loss of $122 \mathrm{CaCO}_{3}$ materials may induce changes in coastlines that are directly created by $\mathrm{CaCO}_{3}$ (i.e., calcareous 123 sand beaches), or those that are shielded from hydrodynamic disturbance due to the baffling effect of 124 offshore $\mathrm{CaCO}_{3}$ ecosystems like coral reefs (Lowe et al., 2009; Andersson and Gledhill, 2013; Comeau 125 et al., 2016). Ecosystems for which the formation of $\mathrm{CaCO}_{3}$ substrates serve an important function, such 126 as shallow water coral reefs, are of concern under continued OA as they provide a vital habitat for 127 numerous other organisms and provide economic, cultural, and social benefits (e.g., Lugo-Fernández et 128 al., 1998; Gratwicke and Speight, 2005).

130 Tropical surface ocean waters in the Caribbean show that calcification rates may have dropped by $\sim 15 \%$ 131 with respect to their pre-industrial values (Friedrich et al., 2012), and $\Omega_{\text {arag }}$ is currently decreasing at a 132 rate of about $3 \%$ per decade (Gledhill et al., 2008; Bates et al., 2012). Perry et al. (2018) found that many 133 shallow coral reefs across the Caribbean are very close to carbonate production and accretion thresholds 134 due to the decline in live coral cover and sea level rise. However, the accretion rates and thresholds 135 presented in Perry et al. (2018) may be lower since reef physical erosion and chemical dissolution were 136 not included in the projections. Tropical near-shore coral reefs could have transitioned from net 137 precipitation to net dissolution (e.g., Muehllehner et al., 2016), but attributing changes in net ecosystem 138 metabolic rates to variations in carbonate chemistry remains challenging in coral reef ecosystems due to 139 the multiple biogeochemical processes affecting coastal waters (Duarte et al., 2013). 
141 Forecasting the effects of continued OA on coral reefs has relied heavily on laboratory and small-scale mesocosm manipulative experiments. The results of these experimental manipulations are often applied to projections of surface ocean carbonate chemistry derived from coupled climate/carbon-cycle models (e.g., Cao and Calderia, 2008). However, most coastal systems exhibit considerably greater complexity than those reproducible in laboratories and expressed in these global models. Seasonal and diurnal variations in seawater carbonate chemistry and $\Omega_{\text {arag }}$ within the reef zone can be several times higher or lower than expected for oceanic waters due to net ecosystem metabolic processes alone (Gattuso et al., 1993; Bates et al., 2010; Turk et al., 2015; Page et al., 2017). The net ecosystem production (NEP, the sum of gross production and respiration processes from all the autotrophic and heterotrophic components of the system) alters the dissolved inorganic carbon (DIC) and the $\left[\mathrm{H}^{+}\right]$concentration and thus can alter the relative partitioning of the carbonate species (Eq.1) and $\Omega_{\text {arag. }}$. Net ecosystem calcification (NEC, the sum of calcium carbonate production and dissolution processes from all biotic and abiotic components of the system) alters the seawater total alkalinity (TA) and DIC in a ratio of 1:2. The combination of NEP and NEC (under constant temperature, salinity, and pressure), change the seawater DIC:TA ratio, which dictates properties such as $\mathrm{pH}, \mathrm{CO}_{2}$ partial pressure $\left(p \mathrm{CO}_{2, \mathrm{sw}}\right)$, and $\Omega$ (Zeebe and Wolf-Gladrow, 2001).

NEC and NEP measurements describe the net accumulation or consumption of inorganic and organic carbon, respectively (e.g., Gattuso et al., 1998). NEC can also be described in terms of the $\mathrm{CaCO}_{3}$ gain and loss due to calcification and chemical dissolution processes. This is necessary to consider in order to quantify the total net accretion rates of the reef substrate (e.g., Eyre et al., 2014). Any decline in NEC relative to NEP could compromise many reef systems, since rates of accretion on healthy, undisturbed reefs only slightly outpace rates of reef loss due to physical and biological erosion (see Glynn and Manzello, 2015). Gradual changes in NEP and NEC can bring the system closer to a 'tipping point' where even small perturbations can cause a shift on the autotrophic-calcifying balance that characterized coral reef ecosystems, to a system dominated by heterotrophic and dissolving conditions (Silbiger et al., 2014; Yeakel et al., 2015). However, discerning whether these net ecosystem metabolic processes are changing 
activities (e.g., eutrophication, OA) is non-trivial and demands sustained robust monitoring at a high temporal resolution, requiring in situ autonomous measurements and in situ water sampling.

Despite the importance of monitoring NEC and NEP using standard best-practices for sustained monitoring of these rates remains a major challenge. NEC and NEP measurements typically adopt various Lagrangian or Eulerian techniques requiring high-temporal resolution of in situ bottle water samples (e.g., Gattuso et al., 1996; Bates, 2002; Silverman et al., 2007). Recently, a few in situ autonomous methods have been proposed which offer great promise, but currently remain cost prohibitive for most networks, and have a limited duration of a few weeks at most due to biofouling and sensor drift (e.g., Yates et al., 1999; McGillis et al., 2011; Falter et al., 2008; Takeshita et al., 2016). Nevertheless, techniques and methods that incorporate existing observations of carbonate chemistry presently allow the development of net ecosystem metabolic proxies that could be employed to monitor these biogeochemical fluxes.

The time series presented here benefits from nine years (from 2009 to 2017) of continuous observations of the carbonate chemistry at the forereef of Enrique coral reef in Puerto Rico. The combined measurements obtained from the moored autonomous $p \mathrm{CO}_{2}\left(\mathrm{Map} \mathrm{CO}_{2}\right)$ buoy technology with a dedicated discrete sampling campaign have provided high-quality observations allowing reasonable constraint of the carbonate system and of the biological processes affecting the water mass as it flows in over the reef platform from the open ocean end member. Moreover, the time series enables us to derive multi-year estimates of NEP and NEC using site-specific empirical relationships derived from both in situ autonomous and discrete bottle data.

In this manuscript, we described the seasonal variability and primary controls of the carbonate system variability and how such dynamics may change as a consequence of OA in the La Parguera near-shore reef system. In order to accomplish this, we tailored our approach to de-couple the biological processes on NEP and NEC, and derived seasonal net ecosystem metabolic rates for the reef system mixed layer using a one-dimensional (1-D) mass balance model developed with the autonomous $\mathrm{MapCO}_{2}$ buoy observations. These metabolic observations serve to provide a more comprehensive interpretation of how 
Biogeosciences Discuss., https://doi.org/10.5194/bg-2018-408

Manuscript under review for journal Biogeosciences

Discussion started: 12 October 2018

(c) Author(s) 2018. CC BY 4.0 License.

(c) (1)

near-shore carbonate chemistry is governed by carbon cycling and to enhance our understanding of the potential long-term impacts of OA on carbonate and energy budgets.

\section{Methods}

\subsection{La Parguera OA Time Series}

The La Parguera OA time series (Fig.1) is an on-going project advanced by the NOAA Coral Reef Conservation Program (CRCP) that was established in 2009. The test-bed has since been adopted as a long-term sustained monitoring station providing physical, chemical, and ecological data under the National Coral Reef Monitoring Program (NCRMP, www.coris.noaa.gov/monitoring/) jointly sponsored by NOAA CRCP and the NOAA Ocean Acidification Program (OAP). Details about the efforts supporting this time series station are described in the supplemental material, S1.

\subsection{Study sites}

The Marine Reserve of La Parguera is located on the southwest coast of Puerto Rico (Fig.2-a). The welldeveloped reef system consists of different habitat types dominated by seagrasses, macroalgal beds, unconsolidated carbonate sediments, and mangroves. The reserve exists in an area with relatively low coastal development, an absence of local rivers, and the lowest rainfall rate in Puerto Rico (Pittman et al., 2010). Local environmental stressors include coastal runoff and fishing (Garcia-Sais et al., 2008).

The insular shelf extends 10-11 km from the coast and is divided in three different regions (inner, middle, and outer shelf reefs) according to its general morphological and depositional characteristics (details in Morelock et al., 1977). The Map $\mathrm{CO}_{2}$ buoy is located at the west-end of the Enrique middle-shelf reef at $2.5 \mathrm{~km}$ from the coast and over the forereef where the water depth is about $3 \mathrm{~m}$ (Fig.2-c).

Cayo Enrique is an emergent reef adjacent to a mangrove system. The back reef and reef flat areas consist of seagrass beds dominated by Thalassia testudinum and a few coral patch reefs. The forereef and the upper zone benthic reef communities at Enrique were formerly dominated by the branching coral Acropora palmata. Significant live coral cover was reduced by $>50 \%$ from 2003 to 2007 (Appeldoorn, 
222 2009). Losses in coral cover are attributed to coral bleaching and disease, and secondarily from 223 hurricanes, and corallivorous mollusks (Morelock et al., 2001; Ballantine et al., 2008). The die-off of the 224 long-spined sea urchin, Diadema antillarum limited coral recovery and prevented recruitment to bare 225 substrates due to the increased algae cover (Ballantine et al., 2008). Currently, most of the area formerly covered by A. palmata is dead and replaced by Millepora spp., Palythoa caribaeorum (zoanthids), and soft corals such as Gorgonia spp. and Pseudopterogorgia spp. McGillis et al. (2011) and Manzello et al. (2017) noted approximately 10 and $11 \%$ live coral cover area during belt transect surveys at the $\mathrm{Ma}^{2} \mathrm{CO}_{2}$ area in March 2009 and August 2015, respectively. The six major reef building corals reported by McGillis et al. (2011) were: Siderastrea siderea, Porites astreoides, Pseudodiploria strigosa, Siderastrea radians, Pseudodiploria clivosa, and Porites porites (ranked in order of areal cover). The dominant 232 benthic communities reported by Manzello et al. (2017) were: sand (30\%), soft coral (25\%), turf algae 233 (17\%), sponges (10\%), and coral rubble (5\%). A survey conducted in 2011 by Moyer et al. (2012), showed 234 that the non-calcifying algal cover was $\sim 25 \%$, with little seasonal variation. However, Pittman et al. 235 (2010) reported a peak of turf algae and macroalgal cover in the summer. Calcifying algae (crustose 236 coralline algae) represent about $1 \%$ of the benthic cover with no significant seasonal variation (Pittman 237 et al., 2010; Moyer et al., 2012).

239 The sediments at the forereef of Enrique consist predominantly of $\mathrm{CaCO}_{3}$, with lesser amounts of terrigenous $(<10 \%)$ and organic material (Ryan et al., 2008; Hernández et al., 2009). According to Morelock et al. (1977) the major $\mathrm{CaCO}_{3}$ contributors are fragments of calcareous green algae (Halimeda spp.), coral fragments (40 to $80 \%$ ), and coralline-algae (10 to $20 \%$ ). It is possible that the relative proportions of the sediment composition and re-distribution have changed over the last 40 years during high-wave energy events (e.g., hurricanes and storms). However, Hernández et al. (2009) found that $\mathrm{CaCO}_{3}$ minerals are still the predominant sediment type at the site, dominated by aragonite and $\mathrm{Mg}$-calcite with 13-14 mol \% $\mathrm{MgCO}_{3}$, and with lesser amounts of $\sim 3 \mathrm{~mol}_{\%} \mathrm{MgCO}_{3}$. These are produced in situ by bioerosion and mechanical processes (Hernández et al., 2009). 
NEP rates were estimated at Enrique forereef during March of 2009 using the boundary layer $\mathrm{O}_{2}$ gradient and enclosure methods (McGillis et al., 2009; McGillis et al., 2011). The average daily NEP rate were 43.1 and $60.3 \mathrm{mmol} \mathrm{C} \mathrm{m}^{-2} \mathrm{~d}^{-1}$ (converted from $\mathrm{O}_{2}$ to $\mathrm{C}$ using the Redfield molar ratio of 138:106) for both methods respectively (McGillis et al., 2011). Results from both methods suggested that during the time of these experiments organic carbon respiration contributed $\mathrm{CO}_{2}$ to reef waters. During the same study the ocean current speeds were measured using a set of ADCPs. The average current speed ranged between 2 to $10 \mathrm{~cm} \mathrm{~s}^{-1}$ towards the west.

Reef areas are flushed by offshore water and typically have water residence times of days to weeks, while longer residence times (months) are found closer to shore (Venti et al., 2012). The residence times from the offshore station and Enrique reef (Fig.2) were measured in 2011 using the inputs and outputs of Beryllium-7 ( $\left.{ }^{7} \mathrm{Be}\right)$ according to Venti et al. $(2012,2014)$. The mean residence times calculated for January and May were 9 and $11 \pm 2$ days (Venti, personal communication), respectively.

\subsection{Autonomous observing capabilities and dataset}

263

The autonomous capability of the $\mathrm{Ma} \mathrm{CO}_{2}$ buoy provides continuous 3-hour measurements of both $\mathrm{CO}_{2 \text {,air }}$ and $\mathrm{CO}_{2, \mathrm{sw}}$ mole fraction $\left(\mathrm{xCO}_{2 \text {,air }}\right.$ and $\left.\mathrm{xCO}_{2, \mathrm{sw}}\right)$. These are converted to $p \mathrm{CO}_{2}$ with total uncertainties of $<1 \mu \mathrm{atm}$ and $<2 \mu \mathrm{atm}$, respectively (Table 1; Sutton et al., 2014a). The buoy is equipped with a seawater-gas equilibrator, reference gas standard, an infrared gas analyzer, Seabird 16/37 conductivity and temperature recorder, and a Sunburst ${ }^{\mathrm{TM}}$ SAMI-pH system located at about $1 \mathrm{~m}$ depth. Details of the $\mathrm{Ma}_{2} \mathrm{CO}_{2}$ instrument calibration and data Quality Assurance and Quality Control (QA/QC) processes are described in Sutton et al. (2014a, 2014b). Final measurements used for the analyses cover from January 2009 to January 2017.

The Map $\mathrm{CO}_{2}$ buoys also have an internal Maxtec ${ }^{\mathrm{TM}} \mathrm{O}_{2}$ sensor (MAX-250+) located inside the $\mathrm{CO}_{2}$ electronics tube (downstream of the infrared gas analyzer sensor) to measure percent of oxygen in air (\% $\mathrm{O}_{2}, \pm 3 \%$ ). These sensors are part of the observational network of all PMEL $\mathrm{CO}_{2}$ buoys, but only intended as a diagnostic tool. The sealed compartment that houses the sensor provides protection from seawater 
Biogeosciences Discuss., https://doi.org/10.5194/bg-2018-408

Manuscript under review for journal Biogeosciences

Discussion started: 12 October 2018

and the effects of marine biofouling, and excessive temperature, humidity, and pressure changes. Despite their diagnostic purpose, they have been shown to offer some utility for studying ocean biological variability (e.g., Xue et al., 2016) even though measurements from the MAX-250+ may not be ideal due to slow $\mathrm{O}_{2}$ equilibration response times (Sutton et al., 2014a). Nevertheless, in an effort to achieve more coherent and usable long-term estimates of $\mathrm{O}_{2}$ concentrations, we obtain reasonable results when we postcalibrate the MAX-250+ using early deployment data from the Aanderraa ${ }^{\mathrm{TM}} \mathrm{O}_{2}$ optode (Aanderaa 4775, 282 accuracy of $\pm 5 \%$ ).

The $\mathrm{O}_{2}$ data obtained by the optode sensor tends to be unreliable for extended deployments of over 6 months as a consequence of biofouling and subsequent sensor drift. Therefore, we proceed under the assumption that they are accurate within specifications for a time period between calibration and prior to any biofouling. The MAX-250+ sensor bias correction was derived from four optode deployments from 2011 to January 2017, and 20 in situ bottle Winkler $\mathrm{O}_{2}$ (Winkler, 1888) measurements collected and analyzed at the CARICOOS lab between 2015 and 2016. The $\mathrm{O}_{2}$ optode measurements were salinity compensated and an internal QA/QC process was applied where the first $\mathrm{O}_{2}$ measurements were removed (considered as the flush to purge residual water and bubbles in the flow lines) and the last two of each cycle averaged. Seawater surface concentration $\left(\mathrm{mmol} \mathrm{m}^{-3}\right)$ is calculated using the $\mathrm{O}_{2}$ solubility (Garcia and Gordon, 1992) as a function of SST and SSS. Linear regression analyses were performed at daily and seasonal time scales (see supplemental material, Fig.S1 and S2) and the best fit $\left(r^{2}=0.90\right.$, RMSE $=3, n$ $=40$ ) was found using the daily averages of the first 40 days after the first deployments, a time interval whereby we judge the data accurate. We corrected the MAX-250+ measurements using the offset and slope (Fig.S1). We also found the corrected $\mathrm{O}_{2}$ measurements agreed reasonably well with the Winkler $\mathrm{O}_{2}$ determinations $\left( \pm 6.85 \mathrm{mmol} \mathrm{m}^{-3}\right)$.

Hourly wind measurements were taken from the nearby NOAA Integrated Coral Observing Network (ICON) station. This station was maintained as an instrumented Coral Reef Early Warning System (CREWS) station from 2006 to 2013 at the Media Luna middle-shelf reef (Fig.2-b), located $1.8 \mathrm{~km}$ south from the $\mathrm{Ma} \mathrm{CO}_{2}$ buoy. In 2015, CARICOOS established a meteorological station at the nearby Marine 
Lab (Fig.2-b), $1.5 \mathrm{~km}$ from the $\mathrm{MapCO}_{2}$ buoy. Wind speed from the ICON and CARICOOS stations were measured at $6.5 \mathrm{~m}$ and $7.8 \mathrm{~m}$ height, respectively. Wind speeds were normalized to a wind speed at $10 \mathrm{~m}$ height according to Hsu et al. (1994) and averaged to every 3 hours. Wind data is taken from this station from 2015 to 2017. Wind data gaps were filled using a climatological curve created with these two datasets. This method was preferred over the use of buoys far from the near-shore study site or satellite wind measurements, as their use tends to overestimate the gas air-sea exchange due their low temporal coverage and limited near-shore spatial coverage (e.g., Jiang et al., 2008). We believe that the coastal topographic setting plays a role in setting up diurnal wind patterns, which are not captured by the remote buoys or the satellite-derived wind speed data.

\subsection{In situ geochemical surveys}

314 Open ocean dynamics in carbonate chemistry are reasonably well constrained and often characterized 315 based on TA-salinity and $p \mathrm{CO}_{2}$-temperature relationships (Lee et al., 2006; Gledhill et al., 2008). 316 However, in near-shore environments benthic and coastal processes can convolute these relationships. 317 Therefore, the autonomous observations were validated and supplemented on a weekly (2009-2013) and 318 bi-weekly (2013-2017) basis through direct measurements of potentiometric TA and spectrophotometric $319 \mathrm{pH}$. Phosphate and silicate concentrations were collected at the buoy site and measured according to 320 Strickland and Parson (1972) six times over the period from 2009 to 2011 in January, February, March, 321 May, November, and December. Details about the collection and analyses procedures of these in situ 322 measurements are available in supplemental material, S2.

324 The average difference between $p \mathrm{CO}_{2, \mathrm{sw}}$ buoy measurements and $p \mathrm{CO}_{2, \mathrm{sw}}$ calculated from in situ bottle 325 samples was $<0.5 \mu \mathrm{atm}$. The average difference between SAMI-pH and spectrophotometric $\mathrm{pH}$ 326 measurements was 0.005 . This data comparability, achieved with widely differing methods, demonstrates 327 the robust quality of our analytical procedures and resulting data. In situ bottle measurements helped with 328 the determination of site-specific algorithms for TA and allowed estimates of DIC and $p \mathrm{CO}_{2, \text { sw }}$ from in 329 situ bottle samples (described in Sect. 2.6.4). These data sets were also used to investigate factors 
controlling the $p \mathrm{CO}_{2, \text { sw }}$ dynamics at the reef station using a 1-D mass conservation model (described in Sect. 2.6).

\section{2}

\subsection{First-order derivations of TA and calculation of carbonic acid system}

TA algorithms based on seawater surface salinity (SSS) and temperature (SST) break down for inshore waters subject to contributions from multiple freshwater end-members and $\mathrm{CO}_{3}{ }^{2-}$ ion variability during calcification and dilution processes (Lee et al., 2006), requiring site-specific relationships to be determined. At the Enrique forereef, in situ bottle TA measurements showed a moderate ( $\left.r^{2}=0.42\right)$, but robust ( $p<0.0001, n=547$ ) correlation to SSS (see supplemental Fig.S3). This was improved with the weak $\left(r^{2}=0.27\right)$, but significant $(p<0.0001, n=548)$ negative correlation with SST. The resultant multivariate linear relationship between TA with SSS and SST produced an $\mathrm{r}^{2}=0.55$ and $p<0.001(\mathrm{n}=$ $547, \mathrm{RMSE}=30$ ). This was used to model TA $\pm 30 \mu \mathrm{mol} \mathrm{kg}{ }^{-1}$ at the reef $\left(\mathrm{TA}_{\text {reef }}\right)$ :

$$
T A_{\text {reef }}=43.2( \pm 0.08) \times S S S-12.5( \pm 0.07) \times S S T+1118( \pm 2.10)
$$

where, the \pm is the standard error of the coefficients.

The reef $\mathrm{CO}_{2}$ - carbonic system was fully solved using $\mathrm{TA}_{\text {reef }}$ and the $p \mathrm{CO}_{2, \mathrm{sw}}$, along with SSS, SST, and pressure ( $1 \mathrm{db}$ - pressure at 1 meter) from the buoy measurements. The MATLAB program $\mathrm{CO}_{2} \mathrm{SYS}$ (van Heuven et al., 2011), applying the dissociation constants for $K_{1}$ and $K_{2}$ of Lueker et al. (2000) and for

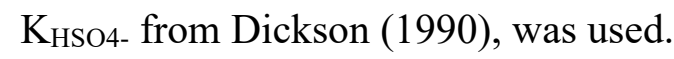

\subsection{Diagnostic mass budget model}

A 1-D mass budget model was used to calculate the net change in $p \mathrm{CO}_{2, \mathrm{sw}}$ based on contributions from the processes controlling the variability of $p \mathrm{CO}_{2, \text { sw }}$ at the surface (e.g., Gruber et al., 1998; Shadwick et al., 2011; Fassbender et al., 2016; Xue et al., 2016). The model is assumed to provide an integrated assessment of biogeochemical variability throughout the well mixed water column as the water mass flows in over the reef-shelf platform from the open ocean end member. The net changes in observed $p \mathrm{CO}_{2, \mathrm{sw}}\left(\delta p \mathrm{CO}_{2 \mathrm{OBS}}\right)$ were calculated from mass the balance as given by: 


\section{(c) (1)}

$\frac{\delta p C O_{2 O B S}}{d t}=\frac{\partial p C O_{2} S O L}{\partial t}+\frac{\partial p C O_{2 A I R-S E A E X}}{\partial t}+\frac{\partial p C O_{2 H O R M I X}}{\partial t}+\frac{\partial p C O_{2 B I O}}{\partial t}$

where, the corresponding daily $\delta p \mathrm{CO}_{2} \mathrm{OBS}$ are from the partial changes $(\partial)$ of gas solubility as a function of SST and SSS (SOL), air-sea exchange (AIR-SEA EX), horizontal mixing processes (HOR MIX), and biological activity (BIO). All the individual parameters used the observed daily means to avoid the effects of high frequency $(<24 \mathrm{hr}$ ) processes (e.g., tides and diurnal biological activity). The data were binned within representative Julian days to create a composite year for each day from 2009 to 2017 (details in 364 Sect. 2.9).

\subsubsection{Thermodynamic variability}

366 The thermodynamic variability $\left(\partial p \mathrm{CO}_{2 \mathrm{SOL}}\right)$ was imposed on the system using daily-observed changes in 367 SST and SSS using the $\mathrm{CO}_{2} \mathrm{SYS}$ program. We preferred this method over the temperature only 368 dependence coefficient $\left(0.0423^{\circ} \mathrm{C}^{-1}\right)$ by Takahashi et al. (1993) as both SSS and SST impart 369 thermodynamic variability in this region and the SST distributions are much different with respect to the 370 waters on which this dependence was derived.

\section{$371 \quad$ 2.6.2 Variation by physical transport}

372 The physical transport attributable to horizontal transport via advection $\left(\partial p \mathrm{CO}_{2 \mathrm{HOR} \text { MIX }}\right)$ was characterized empirically using SSS changes with assumed conservative mixing of TA and DIC between the reef and open ocean (e.g., Xue et al., 2016). Changes due to vertical mixing are neglected and the mixed layer is assumed to extend to the bottom given the small variations on SSS and SST, from the CTD casts performed for the in situ geochemical surveys, and shallowness of the site $(3 \mathrm{~m})$. In addition, three tidbit temperature loggers were deployed one year long from January through December 2015 at different depths along the buoy assembly, showing no thermal stratification in the area. The seasonal change in SSS due to the mean potential evapotranspiration to precipitation rate is assumed to be small $(<0.1 \%)$ and hence neglected. Mixing due to tides is ignored due to the limited diurnal tidal range $(<0.25 \mathrm{~m})$ in the area. 
In situ bottle TA and DIC samples were obtained from seasonal cruises around the Caribbean Region (details in supplemental material, S3), including three cruises to the Caribbean Time Series station (CaTS, 384 Fig.2-b). The linear relationship between TA and SSS measurements ( $\mathrm{n}=237, \mathrm{r} 2=0.99, p<0.001$, RMSE $=4.79)$ was derived to model TA ( TA $\left._{\text {ocean }}\right)$. To model DIC $\left(\mathrm{DIC}_{\text {ocean }}\right)$ a linear relationship $\left(\mathrm{n}=220, \mathrm{r}^{2}=\right.$ $0.93, p<0.001$, RMSE $=12$ ) with SSS and SST was derived. We used the observed daily change in SSS at the buoy to estimate daily changes of TA and DIC from the conservative mixing relationships as follows:

TAocean $( \pm 4.79)=58.9( \pm 0.02) \times S S S+\left(S_{2}-S_{1}\right)+237( \pm 0.900)$

DICocean $( \pm 12)=50.1( \pm 0.25) \times S S S+\left(S_{2}-S_{1}\right)-4.13( \pm 0.16) \times S S T+322( \pm 12.5)$

where, the \pm is the standard error of the coefficients or the RMSE of the derived quantity as applicable, and $S_{1}$ and $S_{2}$ correspond to the salinity at time 1 and 2, respectively. Despite the large uncertainties reported for the physical term using the mass conservation model approach (e.g. Shadwick et al., 2011; Fassbender et al., 2016; Xue et al., 2016), the effect of such uncertainty on subsequent derivations is minimal (details in Sect. 2.10).

\subsubsection{Air-Sea exchange}

399 The effects on $p \mathrm{CO}_{2, \mathrm{sw}}$ due to the physical transport through the air-sea $\mathrm{CO}_{2}$ exchange $\left(\partial p \mathrm{CO}_{2 \mathrm{AIR} \text {-SEA EX }}\right)$ 400 is related to the DIC changes and air-sea $\mathrm{CO}_{2}$ flux $\left(\mathrm{F}_{\mathrm{CO} 2}\right)$. The DIC $\mathrm{CAIR-SEA} \mathrm{EX}\left(\mu \mathrm{mol} \mathrm{\textrm {kg } ^ { - 1 }} \mathrm{day}^{-1}\right)$ is estimated 401 via the change in mixed layer DIC inventory as:

402

$403 D I C_{A I R-S E A E X}=\frac{k s \times\left(f \mathrm{CO}_{2, s w}-f \mathrm{CO}_{2, \text { air }}\right)}{h \rho}$

405 where, $f \mathrm{CO}_{2, \mathrm{sw}}-f \mathrm{CO}_{2}$,air is the difference in atmospheric and seawater $\mathrm{CO}_{2}$ fugacity $\left(f \mathrm{CO}_{2}\right)$ concentration, 406 calculated from the $x \mathrm{CO}_{2}$,air and $x \mathrm{CO}_{2, \text { sw }}$ buoy measurements and converted according to best practices 407 (Dickson et al., 2007; SOP 5) using the virial coefficient of pure $\mathrm{CO}_{2}$ and the virial coefficient of $\mathrm{CO}_{2 \text {,air }}$ 
408 according to Weiss (1974). The $s\left(\mathrm{~mol} \mathrm{~kg}^{-1} \mathrm{~atm}^{-1}\right)$ is the solubility of $\mathrm{CO}_{2}$ per unit volume of seawater 409 (Weiss, 1974), $k\left(\mathrm{~m} \mathrm{~s}^{-1}\right)$ is the transfer velocity as a function of wind speed at $10 \mathrm{~m}$ above mean sea level, $410 h$ is the mixed layer water depth $(\mathrm{m})$, and $\rho$ the seawater density $\left(\mathrm{kg} \mathrm{m}^{-3}\right)$. The transfer velocity-wind 411 speed relationship used is described by Wanninkhof (2014). As a convention in this paper, $\mathrm{O}_{2}$ and $\mathrm{CO}_{2}$ 412 positive fluxes are from the ocean to the atmosphere.

\section{2.6.4 Modulation carbonate parameters by biological processes}

414 The biological processes affecting $p \mathrm{CO}_{2, \mathrm{sw}}\left(\partial p \mathrm{CO}_{2 \mathrm{BIO}}\right)$ were estimated as the residual of the remainder of 415 the other terms on the mass conservation equation (Eq.6) to close the system. The changes on $\partial p \mathrm{CO}_{2 \mathrm{BIO}}$ 416 due to biological activity were defined as:

$418 \frac{\partial p C O_{2 B I O}}{\partial t}=\frac{\partial p C O_{2 N E P}}{\partial t}+\frac{\partial p C O_{2 N E C}}{\partial t}$

420 where $p \mathrm{CO}_{2 \mathrm{NEP}}$ is defined as the processes affecting $p \mathrm{CO}_{2, \mathrm{sw}}$ due to gross photosynthetic production and 421 community respiration and the $p \mathrm{CO}_{2 \mathrm{NEC}}$ refers to the processes affecting $p \mathrm{CO}_{2, \mathrm{sw}}$ due to calcium carbonate 422 gross calcification and gross dissolution.

424 The Revelle Factor $\left(\beta, \partial \ln p \mathrm{CO}_{2, \text { sw }} / \partial \ln\right.$ DIC) was used to convert changes in $\partial p \mathrm{CO}_{2 \mathrm{BIO}}$ to changes in DIC 425 (2DIC $\mathrm{BIO}_{\text {) }}$ using the relation between $p \mathrm{CO}_{2, \mathrm{sw}}$ and DIC as defined by Revelle and Suess (1957). The in 426 situ bottle $\mathrm{pH}$ and TA measurements were used to calculate the in situ bottle $p \mathrm{CO}_{2, \mathrm{sw}}$, the DIC, and the $\beta$. 427 The partial change in DIC due to $p \mathrm{CO}_{2, \mathrm{sw}}\left(\mathrm{DIC} / p \mathrm{CO}_{2, \mathrm{sw}}, \mu \mathrm{mol} \mathrm{\textrm {kg } ^ { - 1 }} \mu \mathrm{tm}^{-1}\right)$ was related to $\beta$. This was 428 linearly related to changes in SST $\left(\mathrm{n}=467, \mathrm{r}^{2}=0.86, \mathrm{p}<0.001\right.$, RMSE $=1.02$; Fig.3). The $\partial p \mathrm{CO}_{2 \mathrm{BIO}}$ was 429 converted to $\partial \mathrm{DIC}_{\mathrm{BIO}}$ according to the following relationship:

$431 \frac{\partial D I C_{B I O}}{\partial t}=\frac{\left(\frac{D I C}{p C O_{2}} \times \frac{\partial p C O_{2 B I O}}{\partial t}\right)}{\beta}$ 


\subsection{Net Ecosystem Production (NEP) and Net Ecosystem Calcification (NEC) rates}

434 The difference between gross ecosystem photosynthetic production and respiration (NEP) was addressed 435 using the observed $\mathrm{O}_{2}\left(\mathrm{O}_{2} \mathrm{OBS}\right)$ measurements and the net $\mathrm{O}_{2}$ air-sea flux $\left(\mathrm{F}_{\mathrm{O} 2}\right)$. The net change in $\mathrm{O}_{2}$ due 436 to organic production is defined as:

$\frac{\partial O_{2 N E P}}{\partial t}=\frac{\partial O_{2 O B S}}{\partial t}-\frac{\partial O_{2 G A S}}{\partial t}$

where, $\partial \mathrm{O}_{2 \mathrm{OBS}}\left(\mathrm{mmol} \mathrm{m}^{-3}\right)$ are the $\mathrm{O}_{2 \mathrm{OBS}}$ changes and the $\partial \mathrm{O}_{2 \mathrm{GAS}}\left(\mathrm{mmol} \mathrm{m}^{-2}\right.$ day $\left.^{-1}\right)$ are the $\mathrm{O}_{2}$ changes due to $\mathrm{F}_{\mathrm{O} 2}$. The $\mathrm{O}_{2}$ fluxes were calculated using the transfer velocity (details in Sect. 2.6.3) and corrected by

442 the bubble flux injection and the bubble flux exchange (Manning and Nicholson, 2016). The changes on $443 \mathrm{O}_{2 \mathrm{NEP}}$ were converted to those of carbon using the Redfield carbon to oxygen molar ratio of 106:138 444 (close to the observed $\mathrm{O}_{2}$ to DIC ratio of 1.1 at Enrique reef) and integrated over the mixed layer.

446 The NEC was estimated using equations (11) and (12) as follows:

$\frac{\partial D I C_{N E C}}{\partial t}=\frac{\partial D I C_{B I O}}{\partial t}-\frac{\partial O_{2 N E P}}{\partial t}$

\subsection{Ecosystem free energy budget}

451 We recast our monthly $\Omega_{\text {arag }}$ climatology in terms of free energy by applying equation 4 and the equations 452 detailed in Morse and Arvidson (2002) for three common mineral phases relevant to coral reef 453 ecosystems: aragonite, $10 \% \mathrm{MgCO}_{3}$, and $15 \% \mathrm{MgCO}_{3}$. From the monthly climatological $\Omega_{\text {arag }}$ values 454 generated from $\mathrm{CO}_{2} \mathrm{SYS}$ we first derived the ion concentration product $(I C P)$ using the stoichiometric 455 solubility product $\left(\mathrm{K}^{*} \mathrm{SP}\right.$, Eq.3) and subsequently converted it to IAP using the ratio of the thermodynamic 456 to stoichiometric solubility products according to: 
460 where, $k_{x}$ is the thermodynamic solubility product for $x$ calcium carbonate mineral phase (Plummer et al., 461 1978).

\subsection{Constructing an annual climatology}

463 We use the average daily observations from 2009 to 2017 to construct the annual climatology for each 464 parameter and derived products to examine the seasonal cycles. The composite year was constructed by 465 binning the data within the representative Julian day. The time series was compiled into two distinct 466 seasons based on the weather in Puerto Rico. The dry and cool season extends from October to March, 467 considered winter. The rainy, humid and hot period runs from April to September and is defined as 468 summer. The seasonal variability was computed using the peak-to-peak amplitude. Details about how the gaps were filled are described in the supplemental material, S4.

\subsection{Error assessments}

471 Model errors for the mass budget model variables (Eq. 6), NEP, and NEC were estimated using Monte 472 Carlo simulations. The same approach was used to estimate the uncertainties of $\mathrm{TA}_{\text {reef, }} \mathrm{DIC}_{\text {reef, }} \mathrm{DIC}_{\mathrm{AIR}}$ 473 SEA EX, DIC $\mathrm{BIO}, \Omega_{\mathrm{arag}}$, and $\beta$ linear regression coefficients. Prior to the Monte Carlo simulations, a 474 normality check was performed using the Kolmogorov-Smirnov test on each of the model variables to 475 verify that the data were normally distributed. Random normal distributions of each model variables 476 (Table 1) were generated using MATLAB. Sampling was repeated 1,000 times to establish the final 477 uncertainty, mean, and standard deviation for each simulation. Details about the error analyses are 478 describe in the supplemental material, S5.

480 The uncertainties associated with the buoy observations are relatively small compared with the 481 uncertainties in TA derived from the conservative mixing with SSS and SST (Eq. 5). This error is large 482 relative to the daily TA changes (which were typically small) and arises largely from non-conservative 483 biological processes, involved with net calcification and net dissolution, which cannot be captured in our 484 linear model. However, we demonstrate that TA uncertainties from the conservative mixing model are 
485 less than the combined uncertainties on the TA anomaly technique from the seawater residence time and depth (Venti et al., 2012; Falter et al., 2013; Teneva et al., 2013; Courtney et al., 2016). The 1-D mass

487 balance approach avoids the errors of the TA-anomaly method and provides accurate estimates of the 488 physical and biological processes. However, better constraint of the $\mathrm{TA}_{\text {reef }}$ would certainly help reduce uncertainties in NEC.

\subsection{Biogeochemical footprint}

491 To better constrain the uncertainty in the horizontal advection term, we used underway measurements of 492 SSS, SST, $\mathrm{O}_{2}, p \mathrm{CO}_{2, \mathrm{sw}}$ collected in November 2016 and March 2017 that were intended to assess the 493 spatial variability around the $\mathrm{MapCO}_{2}$ buoy. These surveys extended from the buoy site to $>1 \mathrm{~km}$ 494 offshore/inshore and incorporated averaged column velocity profiles at the buoy site. The maximum $495 p \mathrm{CO}_{2, \mathrm{sw}}$ change observed during these surveys was $< \pm 0.5 \mu$ atm day ${ }^{-1}$ assuming the maximum observed 496 current speed $\left(7 \mathrm{~cm} \mathrm{~s}^{-1}\right)$ recorded. Our estimated uncertainty of $p \mathrm{CO}_{2}\left( \pm 0.5 \mu \mathrm{atm}\right.$ day $\left.{ }^{-1}\right)$ is based on this 497 observation. Considering a unidirectional $\sim 7 \mathrm{~cm} \mathrm{sec}^{-1}$ current, a daily mean parameter could be 498 influenced by waters up to $\sim 6 \mathrm{~km}$ from the buoy. In actuality, the length scale would be much less 499 considering diurnal changes in tides and wind direction. Further, gradients in carbonate parameters 500 between the different reef sites, seagrass, mangrove channels, sand, and offshore waters tend to be small 501 relative to the temporal changes addressed in this study. Based on these results and Enrique's 502 physicochemical characteristics (e.g., currents, winds, residence times, and SSS changes), we assume that 503 the local river inputs are small and that the forcing from offshore waters occurs at time scales much longer 504 than the reef residence time. Nevertheless, it is important to note that our estimates are not solely 505 influenced by a single reef community and instead are representative of the broader reef-shelf complex 506 system. 


\section{Results}

\section{$508 \quad 3.1$ Seasonal variability of the carbonate chemistry}

509 On an annual scale, the Enrique reef experiences a seasonal SST daily average variations of about $4{ }^{\circ} \mathrm{C}$ 510 (Table 2) with a maximum $30.2^{\circ} \mathrm{C}$ during the summer (September) and a minimum of $26.6^{\circ} \mathrm{C}$ during the 511 winter (January). The SST at the reef is about $1{ }^{\circ} \mathrm{C}$ warmer and 1 salinity unit fresher than the offshore 512 station CaTS. The high temperatures $\left(>30^{\circ} \mathrm{C}\right)$ between August and October coincide with low salinities 513 (Fig.4-a). The SSS seasonal change is about 2 units with a maximum during the summer (April) and a 514 minimum during the winter (November). Increased local rainfall causes recurrent decrease in SSS during 515 the months of June through December. The $\mathrm{DIC}_{\text {reef }}$ and $\mathrm{TA}_{\text {reef }}$ show similar SSS seasonal patterns with 516 maxima in April and minima between September and November (Fig.4-b). The DIC shows a smaller 517 seasonal amplitude $\left(\sim 70 \mu \mathrm{mol} \mathrm{kg}{ }^{-1}\right)$ compared with TA $\left(\sim 100 \mu \mathrm{mol} \mathrm{kg}^{-1}\right)$. Average phosphate and silicate 518 concentrations were $0.032 \pm 0.018 \mu \mathrm{mol} \mathrm{L}^{-1}$ and $1.83 \pm 0.277 \mu \mathrm{mol} \mathrm{L}^{-1}$, respectively. The TA changes 519 attributable to these inorganic nutrients at these concentrations are negligible.

521 Enrique forereef, like many other reefs, is a persistent source of $\mathrm{CO}_{2}$ to the atmosphere $(2.04 \pm 2.13 \mathrm{mmol}$ $522 \mathrm{CO}_{2} \mathrm{~m}^{-2}$ day $^{-1}$ ) with a minimum during the winter and a maximum during the summer (Fig.4-c, Table 2). 523 The seasonal amplitude of the $\mathrm{F}_{\mathrm{CO} 2}$ is about $7 \mathrm{mmol} \mathrm{CO}_{2} \mathrm{~m}^{-2}$ day ${ }^{-1}$ with an annual mean of $0.75 \pm 0.78$ $524 \mathrm{~mol} \mathrm{CO}_{2} \mathrm{~m}^{-2}$ year-1 . Conversely, the maximum net $\mathrm{F}_{\mathrm{O} 2}$ outgassing $\left(14 \mathrm{mmol} \mathrm{O}_{2} \mathrm{~m}^{-2}\right.$ day $\left.^{-1}\right)$ from the ocean 525 to the air occurs during the winter. During the summer, the system is a net sink with a maximum of about $526-90 \mathrm{mmol} \mathrm{O}_{2} \mathrm{~m}^{-2}$ day $^{-1}$ (Fig.4-c, Table 2). Average daily wind speed ranges from $3 \mathrm{~m} \mathrm{~s}^{-1}$ to $6 \mathrm{~m} \mathrm{~s}^{-1}$ and 527 prevailing wind direction from the east and southeast, with little seasonal variation (Fig.4-f, Table 2). The injection of bubbles represents $<2 \%$ of the total $\mathrm{O}_{2}$ flux variation at the site.

530 Figure 4-d shows the $p \mathrm{CO}_{2, \mathrm{sw}}, p \mathrm{CO}_{2, \text { air }}$, and $\mathrm{O}_{2}$ dynamics for the site. Maximum seawater $p \mathrm{CO}_{2, \mathrm{sw}}$ values 531 were observed from August through October (late summer) while minima occurs in February when the 532 surface $p \mathrm{CO}_{2, \mathrm{sw}}$ decreases to near atmospheric equilibrium ( $\left.\sim 390 \mu \mathrm{atm}\right)$. The $p \mathrm{CO}_{2, \mathrm{sw}}$ seasonal amplitude 533 is about $70 \mu \mathrm{atm}$ (Table 2). In contrast, $p \mathrm{CO}_{2 \text {,air }}$ fluctuations were modest ( $13 \mu \mathrm{atm}$ ) and similar to regional 


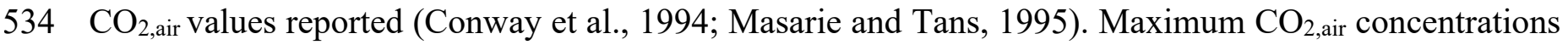
535 are observed from January to May (late winter) and minimum from June through October (late summer). 536 The $\mathrm{O}_{2}$ minimum $\left(154 \mu \mathrm{mol} \mathrm{kg}^{-1}\right)$ occurs during the late summer when the $p \mathrm{CO}_{2, \mathrm{sw}}$ is at a maximum. The 537 annual range of $\mathrm{O}_{2}$ concentration is about $38 \mu \mathrm{mol} \mathrm{kg}-1$ with a maximum $\left(192 \mu \mathrm{mol} \mathrm{kg}^{-1}\right)$ during the 538 winter.

540 The $\mathrm{pH}$ and $\Omega_{\text {arag }}$ show similar patterns with minimum values from August to November ( $\mathrm{pH}<8$ and $\Omega_{\text {arag }}$ $541<3.5$ ) and maximum from March to May (Table 2). The mean $\mathrm{pH}$ is $8.02 \pm 0.01$ with an annual amplitude 542 of 0.07 units. Mean reef $\mathrm{pH}$ conditions during the late summer are $\sim 17 \%$ lower ("more acidic") when 543 compared with the winter (Fig.4-e). The mean $\Omega_{\text {arag }}$ is $3.59 \pm 0.07$ with an annual amplitude of 0.3 units 544 (Table 2). These results are comparable with the seasonal results on Sutton et al., (2016) using the same 545 data set from December 2012 to December 2014.

547 Results from the 1-D mass balance model results shows that the increase in $\partial p \mathrm{CO}_{2 \mathrm{SOL}}$ from May to mid548 October can increase water column $p \mathrm{CO}_{2, \mathrm{sw}}$ up to about $20 \mu \mathrm{atm}$ (Fig.5). During the same season, the 549 air-sea exchange drives the $p \mathrm{CO}_{2, \mathrm{sw}}$ up to about $2 \mu \mathrm{atm}$ decreasing DIC in the water column by only $\sim 5$ $550 \mu \mathrm{mol} \mathrm{kg}{ }^{-1}$. From July through December, the $\partial p \mathrm{CO}_{2 \mathrm{BIO}}$ drives up the water column $p \mathrm{CO}_{2, \mathrm{sw}}$ by about 8 $551 \mu \mathrm{atm}$. The $\partial p \mathrm{CO}_{2 \mathrm{HOR} \text { MIX }}$ does not show a significant seasonal change and we find its contribution to be 552 negligible $(<1 \mu \mathrm{atm})$ throughout the year.

\section{Discussion}

\section{4.1 Net Ecosystem Processes}

555 High TA to DIC slope ( $>0.5)$ from the in situ surveys is observed in Enrique forereef indicating the strong 556 influence of net ecosystem metabolic processes over DIC and TA (Fig.6). High TA to DIC slopes have 557 been used to qualitatively suggest that the system shows net calcification. However, despite Enrique's 558 high TA to DIC slope (1.1) calculated in this study and compared with other reefs areas in the Atlantic 559 and Pacific by Cyronak et al., (2018), the excess of nTA and nDIC relative to adjacent Caribbean oceanic 
values indicate that dissolution and respiration are dominant processes. Figure 6 shows how nTA and $\mathrm{nDIC}$ values are greater than the nTA and nDIC oceanic mean conditions (TA and DIC excess) indicating net ecosystem heterotrophy and carbonate dissolution conditions. It also shows that photosynthesis and calcification slightly dominate at some point in time when the TA and DIC values are below the oceanic mean conditions (TA and DIC consumption). This suggests that the $\mathrm{CO}_{2}$ production during respiration could play an important role on $\mathrm{pH}$ and $\Omega_{\text {arag }}$ dynamics at seasonal time scales.

\section{6}

567

\subsection{Physical and Biological drivers of $p \mathrm{CO}_{2, \mathrm{sw}}$}

The 1-D mass balance model shows that throughout the year, solubility and biological changes are the dominant processes on the water column $p \mathrm{CO}_{2, \text { sw }}$ dynamics at Enrique forereef (Fig.5). The solubility effects are driven by the small SST seasonal variation $\left(4^{\circ} \mathrm{C}\right)$, primarily due to the smaller amplitude in regional air temperatures and therefore, net atmospheric heat flux. The increase in SST during the early summer is the main driver increasing water column $p \mathrm{CO}_{2, \mathrm{sw}}$ and $\mathrm{F}_{\mathrm{CO} 2}$ from July to October. The SSS seasonal change is associated with the regional SSS dynamics from the extension of Amazon and Orinoco river plumes into the northeastern Caribbean (Corredor and Morell, 2001). The cooling and lower DIC pool from the freshwater influx of the regional river plumes have the opposite effect driving the $p \mathrm{CO}_{2, \mathrm{sw}}$ down. Biological processes (NEC and NEP) exert the second most important control on the $p \mathrm{CO}_{2, \text { sw }}$ and $\mathrm{F}_{\mathrm{CO} 2}$ dynamics at this site on an annual scale (details in the next sections). The physical processes, i.e. horizontal transport and the removal of $\mathrm{CO}_{2}$ from the mixed layer via air-sea exchange, play a small role on $p \mathrm{CO}_{2, \mathrm{sw}}$.

\subsection{Net ecosystem metabolism rates}

On an annual basis, the NEP is about $69.5 \pm 9 \mathrm{~g} \mathrm{C} \mathrm{m}^{-2}$ year ${ }^{-1}$ and NEC is about $-581.9 \pm 80 \mathrm{~g} \mathrm{CaCO}_{3} \mathrm{~m}^{-2}$ year ${ }^{-1}$ ) at La Parguera reef shelf system. Under present day conditions the $\mathrm{MapCO}_{2}$ buoy shows that both, dissolution and heterotrophic conditions persists for about 76 \% (278 days) of the year in La Parguera reef system. This is longer than the time interval of dissolution found in the Pacific (Yates and Halley, 2006) and the Western Atlantic (Muehllehner et al., 2016). Our seasonal net ecosystem metabolic measurements are integrated over a longer time scales and spatial extent making difficult to compare with 
studies that are based on short-time reef community diurnal experiments. However, at the uncertainties reported by other methods (e.g., TA-anomaly) this study may not be particularly anomalous in terms of dissolution considering that most of these studies are focused on a specific community. One of the caveats of the method is that is based on ecosystem processes in a near-shore reef zone that includes TA and DIC fluxes that do not originate from the reef. This could mask the coral reef biological signature. Additional studies would be required to evaluate and constraining these processes.

Based on our results, respiration is the major process dominating organic carbon metabolism at the site. Daily rates of NEP reef ranged from -11 to $67 \mathrm{mmol} \mathrm{C} \mathrm{m}^{-2} \mathrm{~d}^{-1}$ (Fig.7-a). Negative NEP $($ NEP $<0)$ values represent net productivity (autotrophy) while positive (NEP $>0$ ) values represent net respiration (heterotrophy). Results on McGillis et al., 2009; McGillis et al., 2011 from the gradient flux (CROSS) and enclosure (SHARQ) methods estimated NEP from March $27^{\text {th }}-29^{\text {th }}$ of 2009 at Enrique reef of about 43.1 $\mathrm{C} \mathrm{mmol} \mathrm{m}^{-2}$ day $^{-1}$ and $60.3 \mathrm{C} \mathrm{mmol} \mathrm{m}^{-2}$ day $^{-1}$, respectively. Our results show an average of 26.3 mmol $\mathrm{C} \mathrm{m}^{-2}$ day $^{-1}$. These rates are similar, but slightly less than the results from CROSS and SHARQ. We believe the discrepancy between estimates is mainly because our model uses measurements taken at the near-surface and thus integrates values over the water column and at some horizontal length scale. In contrast, the CROSS and SHARQ systems measurements are restricted to the benthic boundary. However, all methods showed net heterotrophic conditions during the studied days.

The seasonal rates of NEC range from -58 to $12 \mathrm{mmol} \mathrm{CaCO}_{3} \mathrm{~m}^{-2} \mathrm{~d}^{-1}$ (Fig.7-b). Positive NEC values represent net calcification (NEC $>0$ ) while negative values represent net dissolution (NEC $<0$ ). The average dissolution rate of $-22.6 \mathrm{mmol} \mathrm{m}^{-2}$ day $^{-1}\left(-2.26 \mathrm{~g} \mathrm{~m}^{-2} \mathrm{day}^{-1}\right)$, is at the higher end of rates reported for a coral reef system. Experimental studies have demonstrated that NEC rates are controlled by community composition and environmental conditions (e.g., Langdon and Atkinson, 2005). The high dissolution rates at Enrique forereef may be a function of the area occupied by reef-building corals at the site $(\sim 10 \%)$. Large reductions in live coral cover have occurred across the Caribbean (Gardner et al., 2003). This has caused a shift of reef community structure as most reefs are no longer being dominated by scleractinian corals and this has led to a decrease in calcification rates (Perry et al., 2013). Since our 
614 model tracks the temporal behavior of TA, our high net dissolution rates could be influenced by TA 615 subsidies not accounted for in this study. This includes biotic and abiotic processes at the carbonate 616 sediments and coral rubble that cover around 35\% of the Enrique forereef benthic area. For example, net 617 dissolution rates have been reported for soft bottom/sediment communities (Boucher et al., 1998) and 618 sand (Yates and Halley, 2006) at a rate of $-2.4 \mathrm{mmol} \mathrm{m}^{-2} \mathrm{~d}^{-1}$ and $-3.2 \mathrm{mmol} \mathrm{m}^{-2} \mathrm{~d}^{-1}$, respectively. Another 619 source of TA may arise via anoxic processes in the benthic community (e.g., sulfate reduction).

621 We consider that the 1-D mass balance approach using buoy $p \mathrm{CO}_{2, \mathrm{sw}}$ and $\mathrm{O}_{2}$ observations produces 622 similar NEC and NEP values as the "slack water" (e.g., incubations or mesocosms) and non-enclosure 623 approaches (e.g., gradient flux, Eularian, Lagrangian and control volume of the seawater overlying the 624 benthic community). Our method also addresses their combined influence of benthic and water column 625 processes as well as the effects of $\mathrm{CaCO}_{3}$ dissolution on net ecosystem processes within the mid-shelf reef areas of La Parguera Marine Reserve. It must also be pointed out that our mass balance approach does not provide absolute values for NEP and NEC, but rather provides a climatological view of seasonal 628 changes in the balance of net heterotrophy and net autotrophy and net calcification and net dissolution. 629 We submit that this could prove more useful in terms of coral reef management as a tool to monitor the 630 reef system health across different temporal scales.

632 Further studies to validate this method against other methods that can capture the seasonal variability on 633 NEP and NEC at the site are needed. Validation of the NEC and NEP estimates from this method, either 634 directly or from nutrient or oxygen inventories, along with an understanding of hydrodynamics are needed 635 to constraint the effective footprint of the buoy measurements and to better discern community responses. 636 These additional assessments are necessary to predict the rates and magnitude of OA in near-shore reef 637 ecosystems.

\subsection{Seasonal dynamics and physical drivers of net ecosystem metabolism}

639 The seasonal cycle of NEP indicates that most of the net organic carbon fixation occurs during the winter 640 (Fig.7-a). This resulted in $p \mathrm{CO}_{2}$ values close to atmospheric equilibrium. At the beginning of the winter 
season (December) the system begins to switch from being heterotrophic to autotrophic, indicating that community photosynthetic production in the winter is larger than the respiration (from December to March). While production is an important process throughout the winter, respiration, particularly from June and October, generates a local source of DIC to the system.

646 Gray et al. (2012) observed the same seasonal over-saturation of $p \mathrm{CO}_{2, \mathrm{sw}}$ at nearby Media Luna reef during the summer and fall months from 2007 to 2008 and suggested that net heterotrophy was driven by remineralization of mangrove-derived organic carbon inputs. We speculate that the main drivers of the carbon excesses from mid-April to mid-December include a combination of exposure to exogenous organic carbon sources from inshore mangrove channels and local red mangroves stands. The shoreline of La Parguera urban area is influenced by increased nutrients and turbidity from terrigenous sources (Otero and Carbery, 2005), which would also contain dissolved and particulate organic matter. Such fluxes have been reported as primary threats to near-shore coral reef ecosystems (Garcia-Sais et al., 2008). Observed heterotrophy also coincides with the wet season and the seasonal decrease in SSS caused by the remote influx of freshwater originating from the Orinoco and Amazon River plumes (Corredor and Morell, 2001). Inputs of coastal dissolved organic matter (DOM) and particulate organic matter (POM) from these remote sources may significantly contribute. Continued investigation on coastal organic matter components from local and remote sources will provide additional information on the sources of this excess carbon.

661 We show that net calcification in Enrique forereef is coincident with maximum autotrophy, corresponding with high $\Omega_{\text {arag }}$ and $\mathrm{pH}$. It appears that the increase on net productivity and SSS from January to March may enhance $\Omega_{\text {arag }}$ providing favorable conditions for calcification. This is consistent with the coral reef ecosystem feedback hypothesis (CREF, Bates et al., 2009), where increasing $\Omega_{\text {arag }}$ is stimulated by an increase in net productivity. The combined seasonality in solubility (SST and SSS), and net ecosystem metabolic processes at the site act synergistically to exacerbate OA by depressing surface $\Omega_{\text {arag }}$ and calcification from April to December. Therefore, net ecosystem metabolic processes provide positive 668 feedback driving $\Omega_{\text {arag }}$ down (Fig.8). Namely, continued release of $\mathrm{CO}_{2}$ due to respiration from April to 
December keep $\Omega_{\text {arag }}$ and $\mathrm{pH}$ low, driving metabolic dissolution (Anderson and Gledhill, 2013) which in turn increases $\mathrm{pCO}_{2}$ and lowering $\mathrm{pH}$.

672 The seasonal correlation of $\Omega_{\text {arag }}$ and NEC with SST and SSS is shown in Figure 9. The transition of NEC 673 from net calcifying to net dissolving occurs in April when the seawater $\Omega_{\text {arag }}$ is $<3.6$, SST is $>27$, and 674 SSS is $<35$ (Fig. 9). The biological effects exhibit hysteresis in NEC and $\Omega_{\text {arag, }}$ while the horizontal range

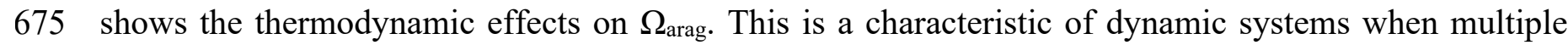
676 drivers can exist for the same set of parameter values (e.g., NEC or NEP). These seasonal shifts can be 677 due to the combined synergy of local terms (thermodynamics, nutrients, light availability and water flow) and regional (river inputs) processes that can influence reef metabolism (e.g., Yeakel et al., 2015; Bates, 2017). Enrique reef shows that when thermodynamic effects increase and $\Omega_{\text {arag }}$ is high (>seasonal mean) the system starts shifting to net calcification and autotrophic conditions (winter: January to March). As

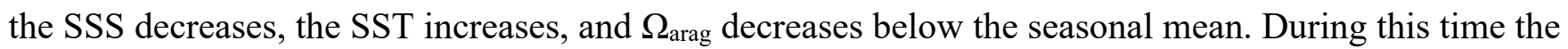
conditions are net heterotrophic and net dissolution rates increase, relative to the values above the $\Omega_{\text {arag }}$ seasonal mean. The underlying NEC- $\Omega_{\text {arag }}$ seasonal hysteresis reflect that $\Omega_{\text {arag }}$ is not the main driver of NEC and that NEP and SST seems to control carbonate precipitation at this site.

\subsection{Net dissolutional conditions}

The average net dissolution at Enrique is about 4 times more than calcification. On an annual basis, the loss in carbonate mass observed in La Parguera from April to December is about $629 \pm 1.6 \mathrm{~g} \mathrm{CaCO}_{3} \mathrm{~m}^{-2}$ year ${ }^{-1}$, a significant $(t$-test, $p<0.0001)$ fraction of the winter calcification rate $\left(40 \pm 0.28 \mathrm{~g} \mathrm{CaCO}_{3} \mathrm{~m}^{-2}\right.$ year $\left.{ }^{-1}\right)$. Considering only the entire forereef area of Enrique $\left(0.0656 \mathrm{~km}^{2}\right.$; Zayas, 2011), this corresponds to a loss of 45 tons of $\mathrm{CaCO}_{3}$ vs 2.9 tons of $\mathrm{CaCO}_{3}$ precipitated. These results indicate that La Parguera

692 shelf reef systems are losing $\mathrm{CaCO}_{3}$ by the process of metabolic dissolution at a rate far faster than 693 production and has already crossed a threshold point for net positive carbonate production. 
Enrique reef is well below the boundary point for where it has been shown that Caribbean reefs shift from net accretion to net erosion (Perry et al., 2013, 2015). Critical calcification/dissolution threshold values have been estimated to occur when $p \mathrm{CO}_{2, \text { sw }}$ between the 450 - $1000 \mu$ atm and $\Omega_{\text {arag }}<3$ (Langdon et al., 2003, Yates and Halley, 2006; Silverman et al., 2007; Andersson et al. 2009; Shamberger et al., 2011; Turk et al., 2015). These thresholds vary from one reef to another as a consequence of benthic community composition, structural complexity (i.e., reactive surface area), variations in residence times (which effect the time-space integration), light, hydrodynamics, and nutrient availability (Yates and Halley, 2006; Silverman et al., 2007; Shamberger et al., 2011). Such thresholds are also dependent on the $\%$ of live coral cover and the combination of erosional, dissolution, and bio-erosional processes at the reef (Perry et al., 2013).

Our model estimates show the system exhibiting net $\mathrm{CaCO}_{3}$ dissolution $(\mathrm{NEC}<0)$ on an annual basis, although $\Omega_{\text {arag }}$ does not exceed the $\Omega_{\text {arag }}$ and $p \mathrm{CO}_{2, \mathrm{sw}}$ thresholds suggested by others. Indeed, dissolution rates at Enrique reef are higher than the levels projected for the 21st century (Eyre et al., 2018). Although, most modern tropical coral reef systems currently reside well above potential critical thresholds to maintain net reef calcification or accretion (Guinotte et al., 2003; Perry et al., 2013, 2015), near-shore Caribbean coral reefs with low live coral cover could have reached these tipping points due to disease and bleaching (linked to high SST), leading to low rates of NEC. For example, discrepancies are found with the results from the census-based carbonate budget data collected at Enrique reef in August 2015 reported a mean net $\mathrm{CaCO}_{3}$ production $1.04( \pm 1.26) \mathrm{kg} \mathrm{m}^{-2}$ year $^{-1}$ and an accretion rate of $0.55 \pm 0.62$ $\mathrm{mm}_{\text {year }}{ }^{-1}$ (Perry et al., 2018). This method suggests that the Enrique reef exhibited positive accretion, 716 albeit minimally and with high variability. These budget surveys are not directly comparable to our NEC 717 rates, as they do not incorporate chemical dissolution and they are based on data obtained from a single 718 point observation in time. In addition, the census approach is based on the sum of the literature estimated 719 calcification rates by individual $\mathrm{CaCO}_{3}$ producers whereas our approach integrated abiotic and biotic processes over the entire reef system. Our current estimates are controlled by a combination of the open ocean end member and biogeochemical and hydrodynamic processes on the reef shelf. The results from 
Biogeosciences Discuss., https://doi.org/10.5194/bg-2018-408

Manuscript under review for journal Biogeosciences

Discussion started: 12 October 2018

seawater chemistry across functional, spatial, and temporal scales. Further refinement of our model is required to better understand the carbonate chemistry variability at each functional community scale.

726 The highest rates of net dissolution occur during periods when rates of net heterotrophy are at their 727 highest. This corresponds to the periods when highly soluble minerals, cements, and organisms such as crustose coralline algae exhibit net dissolution. An increase in the magnitude or time of occurrence of net dissolution could become a serious threat to the formation of sediments, reefs, and other structures composed of $\mathrm{CaCO}_{3}$ (Eyre et al., 2014; 2018). It is clear, that under continued periods of net dissolution, net reef accretion is jeopardized in the face of other climate stressors (e.g. coral bleaching and ocean warming). Our model, coupled to the $\mathrm{Ma} \mathrm{CO}_{2}$ data provides the ability to monitor and understand nearshore carbonate chemistry variability to assess, forecast, and model the impacts of OA on near-shore reef ecosystems. Prior to design of measures that may effectively ameliorate the impact of OA on tropical shallow coral reefs ecosystems and allow us to improve current management strategies; we need to develop a detailed understanding of the carbon cycle role in net ecosystem metabolic "performance". This will aid in the identification and development of effective adaptation mitigation strategies that could reduce local carbon inputs and decrease erosional processes.

\subsection{Free energy dynamics at La Parguera Near-Shore Reef ecosystems}

740 The use of $\Omega_{\text {arag }}$ as an index of coral health has perhaps been over-utilized in the OA literature to date, with few instances of explicit acknowledgment of what the index truly represents nor the key assumptions implied when adopting its use. Firstly, when considering the use of $\Omega_{\text {arag }}$ within the context of a coral reef ecosystem, it should be appreciated that a coral reef comprises a heterogeneous composition of a range of $\mathrm{CaCO}_{3}$ minerals. While aragonite dominates, considerable amounts of magnesium carbonate with variable ranges in magnesium content are also present. Furthermore, the stoichiometric solubility product used by CO2SYS to generate the $\Omega_{\text {arag }}$ value is experimentally derived using abiotic aragonite while the vast majority of $\mathrm{CaCO}_{3}$ minerals deposited on coral reefs are biogenically derived. The behaviour of these biogenically produced minerals is complex in seawater owing to the important role of kinetics so care must be taken to avoid over-interpreting a reported saturation state with a complex marine system such 
Biogeosciences Discuss., https://doi.org/10.5194/bg-2018-408

Manuscript under review for journal Biogeosciences

Discussion started: 12 October 2018

(c) Author(s) 2018. CC BY 4.0 License.

Discussions

(c) (1)

as the La Parguera (see review by Morse et al., 2007). Finally, it should be remembered that saturation state is fundamentally related to the free energy of the system to drive the reaction which can be capitalized by marine organisms. While corals have evolved a range of mechanisms to induce calcification (at least adult life stages), these are energy intensive processes having to overcome the kinetic barriers to calcification. The less free energy available in the ambient environment to drive reaction, the more energy corals will need to utilize for calcification.

The annual median free energy available to drive mineral precipitation for this Caribbean system are given in Table 3. On the La Parguera shelf reef system, net dissolution would be favored for Mg-calcite with $>28 \mathrm{~mol} \% \mathrm{MgCO}_{3}$. It is important to consider that the free energies shown here are based on solubilities for synthetic mineral phases while biogenic phases are considerably more soluble (Busenberg and Plummer, 1989). This would imply that the "true" free energies may be only a fifth that derived here owing to their distinct differences in physical properties, composition, structure, and reactivity relative to synthetic phases which are commonly assumed (Morse et al., 2007).

Adult marine calcifiers deploy a range of strategies to overcome this inhibition and drive the reaction at rates that often depart significantly from abiotic processes. However, the initial energy available to drive the reaction is reflected in the free energy pool of the ambient seawater. Whatever energy deficit may exist between the ambient pool and that needed to induce nucleation is energy that the organism must contribute itself. Due to the seasonal dynamics in free energy at Enrique reef, a coral must contribute an additional $\sim 85 \mathrm{cal} \mathrm{mol}^{-1} \mathrm{CaCO}_{3}$ in the late fall relative to the spring regardless of the mineral phase being considered (Fig. 10).

This seasonal dynamic is relatively minor in comparison with the loss of the free energy that has been depleted from the system due to OA since the pre-industrial period, which has likely been greater than $155 \mathrm{cal} \mathrm{mol}^{-1} \mathrm{CaCO}_{3}$. By the end of the century under business-as-usual we can expect a loss $\sim 337 \mathrm{cal}$ $\mathrm{mol}^{-1}$ with respect to pre-industrial values, which will need to be compensated for by marine calcifiers in this system if they are going to maintain calcification. 


\section{Conclusions}

779 Net heterotrophy and net dissolution dominate over most of the year on the Enrique forereef and off-reef 780 areas while net autotrophic conditions coupled with calcification dominated from only January to mid781 April (winter). The seasonal hysteresis between NEC and $\Omega_{\text {arag }}$ suggest that $\Omega_{\text {arag }}$ is not the main driver of 782 NEC at the site. The NEC dynamics are mainly controlled by NEP and SST and reflect the combination 783 of the biogeochemical and hydrodynamic processes on the reef shelf from the open ocean waters. This 784 carbon subsidy likely originated from nearby mangroves and autochthonous benthic processes with much 785 of the dissolution generated within the sediments and reef framework. The Enrique forereef serves as a 786 continuous net source of $\mathrm{CO}_{2}$ to the atmosphere. This is largely driven by the seasonal cycle of SST. The 787 thermodynamics and metabolic activity are the dominant processes influencing the $p \mathrm{CO}_{2, \text { sw }}$ changes at 788 Enrique forereef, with air-sea $\mathrm{CO}_{2}$ gas exchange and advective processes having minor impacts on the 789 carbonate chemistry over the 2009 - 2017 period.

791 Constraining the local near-reef variability in carbonate chemistry across diel, seasonal, and annual scales 792 is an important step in determining potential biogeochemical thresholds to OA for specific reef 793 environments. At seasonal timescales, the Enrique net reef community metabolism may also affect the 794 reef's susceptibility to pressures from OA. It is likely that Enrique Reef and other nearby reefs in La 795 Parguera are already experiencing prolonged periods of net dissolution driven by high respiration rates. 796 Future projections of the net erosional processes (chemical and biological) can be anticipated, assuming 797 that surface waters continue to increase in accordance with current trends in $\mathrm{CO}_{2}$ and temperature. While 798 these waters will remain supersaturated with respect to aragonite for at least several centuries, the most

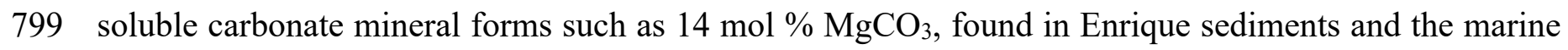
800 lithified (cements) in the coral reef framework, are likely to experience prolonged undersaturation on an 801 annual basis. This also have implications on the coral energy required to maintain active calcification 802 during periods of low free energy. Based on similarities in environmental characteristics, our results 803 suggest that tropical Caribbean reef ecosystems are exhibiting periods of net dissolution. 
Biogeosciences Discuss., https://doi.org/10.5194/bg-2018-408

Manuscript under review for journal Biogeosciences

Discussion started: 12 October 2018

(c) Author(s) 2018. CC BY 4.0 License.

Discussions

(c) (1)

805 Our results demonstrate that current sustained high temporal robust autonomous capabilities of buoyed operational systems such as the La Parguera $\mathrm{MapCO}_{2}$ buoy can be used to detect metabolic processes sensitive to OA. Future research efforts should be directed to combine different techniques and in situ methods for model validation in order to gain a better understanding of ecosystem changes across different temporal scales. Our methods yield a valuable index of cumulative net ecosystem effects of the biological processes affecting the water column over the reef. It is also important to note that we use data from fixed assets and that the methods may be scaled wherever similar data streams are found. Such results can be

812 used to establish critical baselines against which future comparisons can be made, thus enabling 813 evaluation of coral reef health and changes attributable to multiple stressors including OA. Further, high 814 frequency data provided by this and similar operational systems can be used to develop early warning capabilities needed to identify and predict ecological community changes.

\section{Data availability}

817 The $\mathrm{CO}_{2}$ buoy data are archived on the Ocean Carbon Data System (OCADS) at 818 https://www.nodc.noaa.gov/ocads/data/0117354.xml; Sutton et al., (2014b).

820 The data from the ICON station is archived on National Centers for Environmental Information (NCEI) 821 at https://www.nodc.noaa.gov/archive/arc0072/0124000/1.1/data/1-data/icon-lppr1-2013-data.csv;

822 Hendee (2014).

The discrete data are archived on the NCEI at http://www.nodc.noaa.gov/oceanacidification/data/0145164.xml; Melendez et al. (2016).

The benthic community cover data are archived on the NCEI at https://data.nodc.noaa.gov/cgibin/iso?id=gov.noaa.nodc:0157740; Manzello et al. (2017).

\section{Competing interests}

830 The authors declare that they have no conflict of interest. 
Biogeosciences Discuss., https://doi.org/10.5194/bg-2018-408

Manuscript under review for journal Biogeosciences

Discussion started: 12 October 2018

(c) Author(s) 2018. CC BY 4.0 License.

\section{Acknowledgements}

832 Support for this study was provided by the NOAA's Coral Reef Conservation Program through its AOAT project and the Ocean Acidification Program (OAP). UPRM participation in the latter is made possible through the IOOS partnership with CARICOOS program. We would like to give special thanks to Dr. Jorge Corredor for the opportunity of working with him and his work throughout the development of the AOAT. We also thank the staff and students of the UPRM Marine Sciences Department and UNH for field and lab assistance. We thank Helena Antoun, Belitza Brocco, Val Hensley and Erick García from UPRM for the assistance provided with the field and laboratory samples. We would like to thank Alyson Venti for providing the Be-7 sampling and residence time analyses. The authors are grateful for the constructive comments from Chris Hunt and Tyler Winsor. PMEL contribution number 4830 .

\section{References}

Albright, R. and Mason, B.: Projected Near-Future Levels of Temperature and pCO2 Reduce Coral

Albright, R. A., Mason, B., Miller, M., and Langdon, C.: Ocean acidification compromises recruitment success of the threatened Caribbean coral, Acropora palmata, Proc. Natl. Acad. Sci. U.S.A., 107, 20400-20404, 2010.

Andersson, A. J., and Gledhill, D.: Ocean acidification and coral reefs: effects on breakdown, dissolution, and net ecosystem calcification, Ann. Rev. Mar. Sci., 5, 321-48, doi:10.1146/annurev-marine-121211-172241, 2013.

Andersson, A. J., Kuffner, I. B., Mackenzie, F. T., Jokiel, P. L., Rodgers, K. S., and Tan, A.: Net loss of $\mathrm{CaCO}_{3}$ from coral reef communities due to human induced seawater acidification, Biogeosciences Discuss., 6(1), 2163 2182, doi:10.5194/bgd-6-2163-2009, 2009.

Anthony, K. R. N., Kline, D. I., Diaz-Pulido, G., Dove, S., and Hoegh-Guldberg, O.: Ocean acidification causes bleaching and productivity loss in coral reef builders, Proc. Natl. Acad. Sci. U.S.A., 105(45), 17442-6, doi:10.1073/pnas.0804478105, 2008.

Appeldoorn, R.S., Yoshioka, P.M., and Ballantine, D.L.: Coral reef ecosystem studies: Integrating science and management in the Caribbean, Caribb. J. Sci., 45(2-3),134-137, 2009.

Ballantine, D.L., Appeldoorn, R.S., Yoshioka, P., Weil, E., Armstrong, R., Garcia, J.R., Otero, E., Pagan, F., Sherman, C., Hernandez-Delgado, E.A., Bruckner, A., and Lilyestrom, C.: Biology and Ecology of Puerto Rican Coral Reefs, In Riegl BM, Dodge RE (eds) Coral Reefs of the USA. Springer, Berlin, 375-406, 2008. 
Biogeosciences Discuss., https://doi.org/10.5194/bg-2018-408

Manuscript under review for journal Biogeosciences

Discussion started: 12 October 2018

(c) Author(s) 2018. CC BY 4.0 License.

Bates, N. R., Amat, A., and Andersson, A. J.: Feedbacks and responses of coral calcification on the Bermuda reef system to seasonal changes in biological processes and ocean acidification, Biogeosciences, 7(8), 2509-2530, doi:10.5194/bg-7-2509-2010, 2010.

Bates, N. R., Amat, A. and Andersson, A. J.: The interaction of ocean acidification and carbonate chemistry on coral reef calcification: evaluating the carbonate chemistry Coral Reef Ecosystem Feedback (CREF) hypothesis on the Bermuda coral reef, Biogeosciences Discuss., 6(4), 7627-7672, doi:10.5194/bgd-6-7627-2009, 2009.

Bates, N. R.: Seasonal variability of the effect of coral reefs on seawater $\mathrm{CO}_{2}$ and air-sea $\mathrm{CO}_{2}$ exchange, Limnol. Oceanogr., 47(1), 43-52, doi:10.4319/1o.2002.47.1.0043, 2002.

Bates, N. R., Best, M. H. P., Neely, K., Garley, R., Dickson, A. G., and Johnson, R. J.: Detecting anthropogenic carbon dioxide uptake and ocean acidification in the North Atlantic Ocean, Biogeosciences, 9(7), 2509-2522, doi:10.5194/bg-9-2509-2012, 2012.

Bates, N. R.: Twenty Years of Marine Carbon Cycle Observations at Devils Hole Bermuda Provide Insights into Seasonal Hypoxia, Coral Reef Calcification, and Ocean Acidification, Front. Mar. Sci., 4, 1-23, doi:10.3389/fmars.2017.00036, 2017.

Borowitzka, M. A.: Photosynthesis and calcification in the articulated coralline red algae Amphiroa anceps and A. foliacea, Mar. Biol., 62, 17-23, 1981.

Boucher, G., Clavier, J., Hily, C. and Gattuso, J.-P.: Contribution of soft-bottoms to the community metabolism (primary production and calcification) of a barrier reef flat (Moorea, French Polynesia), J. Exp. Mar. Bio. Ecol., 225(2), 269-283, doi:10.1016/S0022-0981(97)00227-X, 1998.

Busenberg, E. and Plummer, L. N.: Thermodynamics of magnesian calcite solid-solutions at $25{ }^{\circ} \mathrm{C}$ and $1 \mathrm{~atm}$ total pressure, Geochim. Cosmochim. Ac., 53, 1189-1208, 1989.

Cao, L., and Caldeira, K.: Atmospheric $\mathrm{CO}_{2}$ stabilization and ocean acidification, Geophys. Res. Lett., 35(19), 15, doi:10.1029/2008GL035072, 2008.

Chan, N. C. S., and Connolly, S. R.: Sensitivity of coral calcification to ocean acidification: a meta-analysis. Glob. Chang. Biol. 19, 282-290, doi: 10.1111/gcb.12011, 2013.

Cohen, A. L. L. and Holcomb, M.: Why corals care about ocean acidification: Uncovering the mechanism, Oceanography, 22(4), 118-127, 2009.

Comeau, S., Lantz, C. A., Edmunds, P. J., and Carpenter, R. C.: Framework of barrier reefs threatened by ocean acidification, Glob. Chang. Biol., 22(3), doi:10.1111/gcb.13023, 2016.

Conway, T. J., Tans, P. P., Waterman, L. S., Thoning, K. W., Kitzis, D. R., Masarie, K. A., and Zhang, N.: Evidence for interannual Variability of the carbon cycle from the National Oceanic and Atmospheric Administration/Climate Monitoring and Diagnostics Laboratory global air sampling network, J. Geophys. Res., 99, 22831-22855,1994. 
Biogeosciences Discuss., https://doi.org/10.5194/bg-2018-408

Manuscript under review for journal Biogeosciences

Discussion started: 12 October 2018

(c) Author(s) 2018. CC BY 4.0 License.

Corredor, J. E., and Morell, J. M.: Seasonal variation of physical and biogeochemical features in eastern

Courtney, T. A., Andersson, A. J., Bates, N. R., Collins, A., Cyronak, T., de Putron, S. J., Eyre, B. D., Garley, R., Hochberg, E. J., Johnson, R., Musielewicz, S., Noyes, T. J., Sabine, C. L., Sutton, A. J., Toncin, J., and Tribollet, A.: Comparing Chemistry and Census-Based Estimates of Net Ecosystem Calcification on a Rim Reef in Bermuda, Front. Mar. Sci., 3, 181, doi:10.3389/fmars.2016.00181, 2016.

Cyronak, T., Andersson, A. J., Langdon, C., Albright, R., Bates, N. R., Caldeira, K., Carlton, R., Corredor, J. E., Dunbar, R. B., Enochs, I., Erez, J., Eyre, B. D., Gattuso, J.-P., Gledhill, D., Kayanne, H., Kline, D. I., Koweek, D. A., Lantz, C., Lazar, B., Manzello, D., McMahon, A., Meléndez, M., Page, H. N., Santos, I. R., Schulz, K. G., Shaw, E., Silverman, J., Suzuki, A., Teneva, L., Watanabe, A., and Yamamoto, S.: Taking the metabolic pulse of the world's coral reefs, PLoS One, 13(1), e0190872, 2018.

Dickson, A. G.: Thermodynamics of the dissociation of boric acid in potassium chloride solutions from 273.15 to 318.15 K, J. Chem. Eng. Data., 35(3), 253-257, 1990.

Dickson, A. G., Sabine, C. L., and Christian, J. R.: Guide to best practices for ocean $\mathrm{CO}_{2}$ measurements. Sidney, British Columbia, North Pacific Marine Science Organization, PICES Special Publication 3, 2007.

Doropoulos, C., Ward, S., Diaz-Pulido, G., Hoegh-Guldberg, O., Mumby, P.J.: Ocean acidification reduces coral recruitment by disrupting intimate larval-algal settlement interactions, Ecology Letters, 15, 338-346, 2012.

Duarte, C. M., Hendriks, I. E., Moore, T. S., Olsen, Y. S., Steckbauer, A., Ramajo, L., Carstensen, J., Trotter, J. A., and McCulloch, M.: Is Ocean Acidification an Open-Ocean Syndrome? Understanding Anthropogenic Impacts on Seawater pH, Estuaries and Coasts, 36(2), 221-236, doi:10.1007/s12237-013-9594-3, 2013.

Eyre, B. D., Andersson, A. J., and Cyronak, T.: Benthic coral reef calcium carbonate dissolution in an acidifying ocean, Nat. Clim. Chang., 4(11), 969-976, doi:10.1038/nclimate2380, 2014.

Eyre, B. D., Cyronak, T., Drupp, P., Carlo, E. H. De, Sachs, J. P., and Andersson, A. J.: Dissolving Before End of Century, 911, 908-911, doi:10.1126/science.aao1118, 2018.

Falter, J. L., Lowe, R. J., Atkinson, M. J., Monismith, S. G., and Schar, D. W.: Continuous measurements of net production over a shallow reef community using a modified Eulerian approach, J. Geophys. Res., 113(C7), C07035, doi:10.1029/2007JC004663, 2008.

Falter, J. L., Lowe, R. J., Zhang, Z., and McCulloch, M.: Physical and biological controls on the carbonate chemistry of coral reef waters: effects of metabolism, wave forcing, sea level, and geomorphology, PLoS One, 8(1), e53303, doi:10.1371/journal.pone.0053303, 2013.

Fassbender, A. J., Sabine, C. L., and Feifel, K. M.: Consideration of coastal carbonate chemistry in understanding biological calcification, 43(9), 4467-4476, doi:10.1002/2016GL068860, 2016.

Friedrich, T., Timmermann, a, Abe-Ouchi, a, Bates, N. R., Chikamoto, M. O., Church, M. J., Dore, J. E., Gledhill, D. K., González-Dávila, M., Heinemann, M., Ilyina, T., Jungclaus, J. H., McLeod, E., Mouchet, a and 
Biogeosciences Discuss., https://doi.org/10.5194/bg-2018-408

Manuscript under review for journal Biogeosciences

Discussion started: 12 October 2018

(C) Author(s) 2018. CC BY 4.0 License.

Santana-Casiano, J. M.: Detecting regional anthropogenic trends in ocean acidification against natural variability, 
Biogeosciences Discuss., https://doi.org/10.5194/bg-2018-408

Manuscript under review for journal Biogeosciences

Discussion started: 12 October 2018

(c) Author(s) 2018. CC BY 4.0 License.

002

003

004

005

006

007

008

009

Integrated Coral Observing Network (ICON) - Media Luna Reef (LPPR1 - La Parquera Natural Reserve, Puerto Rico) Meteorological and Oceanographic Observations from 2013-01-01 to 2013-03-20 (NODC Accession 0124000). Version 1.1. National Oceanographic Data Center, NOAA. Dataset.

Hernández, R., Sherman, C., Weil, E., and Yoshioka, P.: Spatial and temporal patterns in reef sediment accumulation and composition, southwestern insular shelf of Puerto Rico, Caribb. J. Sci., 45(2-3), 138-150, 2009.

Hsu, S. A., Meindl, E. A. and Gilhousen, D. B.: Determining the Power-Law Wind-Profile Exponent under NearNeutral Stability Conditions at Sea, J. Appl. Meteorol., 33(6), 757-765, doi:10.1175/15200450(1994)033<0757:DTPLWP>2.0.CO;2, 1994.

IPCC: Climate Change 2014: Synthesis Report. Contribution of Working Groups I, II and III to the Fifth Assessment Report of the Intergovernmental Panel on Climate Change. Core Writing Team, R.K. Pachauri and L.A. Meyer (eds) Geneva, Switzerland, 151, 2014.

Jiang, L.-Q., Cai, W.-J. W.-J., Wanninkhof, R., Wang, Y. and Lüger, H.: Air-sea CO2 fluxes on the U.S. South Atlantic Bight: Spatial and seasonal variability, J. Geophys. Res., 113(C7), 1-17, doi:10.1029/2007jc004366, 2008.

Kinsey, D.W.: Metabolism, calcification and carbon production. I. System Level Studies. Proceedings of the 5th International Coral Reef Congress, Tahiti, 22, 1985.

Kleypas, J. A., Buddemeier, R. W., Archer, D., Gattuso, J. P., Langdon, C., and Opdyke, B. N.: Geochemical consequences of increased atmospheric carbon dioxide on coral reefs, Science, 284,118--120, 1999.

Langdon, C., and Atkinson, M. J.: Effect of elevated $\mathrm{pCO}_{2}$ on photosynthesis and calcification of corals and interactions with seasonal change in temperature/irradiance and nutrient enrichment, J. Geophys. Res. Ocean., 110(C9), 1-16, doi:10.1029/2004JC002576, 2005.

Langdon, C., Takahashi, T., Sweeney, C., Chipman, D., Goddard, J., Marubini, F., Aceves, H., Barnett, H., and Atkinson, M.: Effect of calcium carbonate saturation state on the calcification rate of an experimental coral reef, Global Biogeochem. Cycles, 14(2), 639-654, 2000.

Langdon, C., Broecker, W. S., Hammond, D. E., Glenn, E., Fitzsimmons, K., Nelson, S. G., Peng, T.-H., Hajdas, I., and Bonani, G.: Effect of elevated $\mathrm{CO} 2$ on the community metabolism of an experimental coral reef, Global Biogeochem. Cycles, 17(1), doi:10.1029/2002GB001941, 2003.

Le Quéré, C., Andrew, R. M., Canadell, J. G., Sitch, S., Ivar Korsbakken, J., Peters, G. P., Manning, A. C., Boden, T. A., Tans, P. P., Houghton, R. A., Keeling, R. F., Alin, S., Andrews, O. D., Anthoni, P., Barbero, L., Bopp, L., Chevallier, F., Chini, L. P., Ciais, P., Currie, K., Delire, C., Doney, S. C., Friedlingstein, P., Gkritzalis, T., Harris, I., Hauck, J., Haverd, V., Hoppema, M., Klein Goldewijk, K., Jain, A. K., Kato, E., Körtzinger, A., Landschützer, P., Lefèvre, N., Lenton, A., Lienert, S., Lombardozzi, D., Melton, J. R., Metzl, N., Millero, F., Monteiro, P. M. S., Munro, D. R., Nabel, J. E. M. S., Nakaoka, S. I., O’Brien, K., Olsen, A., Omar, A. M., Ono, T., Pierrot, D., Poulter, B., Rödenbeck, C., Salisbury, J., Schuster, U., Schwinger, J., Séférian, R., Skjelvan, I., Stocker, B. D., Sutton, A. J., Takahashi, T., Tian, H., Tilbrook, B., Van Der Laan-Luijkx, I. T., Van Der Werf, G. 
Biogeosciences Discuss., https://doi.org/10.5194/bg-2018-408

Manuscript under review for journal Biogeosciences

Discussion started: 12 October 2018

(c) Author(s) 2018. CC BY 4.0 License.

R., Viovy, N., Walker, A. P., Wiltshire, A. J. and Zaehle, S.: Global Carbon Budget 2016, Earth Syst. Sci. Data, 8(2), 605-649, doi:10.5194/essd-8-605-2016, 2016.

Leclercq, N., Gattuso, J. P., and Jaubert, J.E.A.N.: $\mathrm{CO}_{2}$ partial pressure controls the calcification rate of a coral community, Glob. Chang. Biol., 6(3), 329-334, doi:10.1046/j.1365-2486.2000.00315.x, 2000.

Leclercq, N., Gattuso, J. P., and Jaubert, J.: Primary production, respiration and calcification of a coral reef mesocosm under increased $\mathrm{CO}_{2}$ partial pressure, Limnol. Oceanogr., 47(2), 558- 564, 2002.

Lee, K., Choi, S. D., Park, G. H., Wanninkhof, R., Peng, T. H., Key, R. M., Sabine, C. L., Feely, R. A., Bullister, J. L., Millero, F. J., and Kozyr, A.: An updated anthropogenic $\mathrm{CO}_{2}$ inventory in the Atlantic Ocean, Global Biogeochem. Cy., 17(4), 1116, doi:10.1029/2003GB002067, 2003.

Lee, K., Tong, L. T., Millero, F. J., Sabine, C. L., Dickson, A. G., Goyet, C., Park, G.-H. H., Wanninkhof, R., Feely, R. A., and Key, R. M.: Global relationships of total alkalinity with salinity and temperature in surface waters of the world's oceans, Geophys. Res. Lett., 33(19), 1-5, doi:10.1029/2006GL027207, 2006.

Lowe, R. J., Falter, J. L., Monismith, S. G., and Atkinson, M. J.: A numerical study of circulation in a coastal reef-lagoon system, J. Geophys. Res. Ocean., 114(6), 873-893, doi:10.1029/2008JC005081, 2009.

Lueker, T. J., Dickson, A. G. and Keeling, C. D.: Ocean pCO2 calculated from dissolved inorganic carbon, alkalinity, and equations for $\mathrm{K} 1$ and $\mathrm{K} 2$ : validation based on laboratory measurements of $\mathrm{CO} 2$ in gas and seawater at equilibrium, Mar. Chem., 70(1), 105-119, doi:https://doi.org/10.1016/S0304-4203(00)00022-0, 2000.

Lugo-Fernández, A., Roberts, H. H., and Suhayda, J. N.: Wave transformations across a Caribbean fringingbarrier Coral Reef, Cont. Shelf Res., 18(10), 1099-1124, doi:10.1016/S0278-4343(97)00020-4, 1998.

Manning, C. C., and Nicholson, D. P.: Gas_toolbox: MATLAB code used in Manning et al. GTWS-7 proceedings. Zenodo. DOI: 10.5281/zenodo.45293, 2016.

Manzello, D., Enochs, I., Valentino, L., Kolodziej, G., Carlton, R., Jones, P.: National Oceanic and Atmospheric Administration; Cooperative Institute for Marine and Atmospheric Studies. National Coral Reef Monitoring Program: Carbonate Budget data of Cayo Enrique near La Parguera, Puerto Rico from 2015-08-03 to 2015-08-07 (NCEI Accession 0157740). Version 1.1. NOAA National Centers for Environmental Information. Dataset, 2017.

Marshall, A. T., and Clode, P. L.: Effect of increased calcium concentration in sea water on calcification and photosynthesis in the scleractinian coral Galaxea fascicularis, J. Exp. Biol., 205, 2107-2113, 2002.

Marubini, F., Barnett, H., Langdon, C., and Atkinson, M.: Dependence of calcification on light and carbonate ion concentration for the hermatypic coral Porites compressa, Mar. Ecol. Prog. Ser., 220, 153-162, doi:10.3354/meps220153, 2001.

Masarie, K. A., and Tans, P. P.: Extension and integration of atmospheric carbon dioxide data into a globally consistent measurement record, J. Geophys. Res.-Atmos., 100, 11593-11610, 1995. 
Biogeosciences Discuss., https://doi.org/10.5194/bg-2018-408

Manuscript under review for journal Biogeosciences

Discussion started: 12 October 2018

(c) Author(s) 2018. CC BY 4.0 License.

McGillis, W. R., Langdon, C., Williams, A. J. and Loose, B.: O2 -MAVS: an Instrument for Measuring Oxygen Flux, in OCEANS 2009, pp. 1-9., doi:10.23919/OCEANS.2009.5422166, 2009.

McGillis, W. R., Langdon, C., Loose, B., Yates, K. K., and Corredor, J. E.: Productivity of a coral reef using boundary layer and enclosure methods, Geophys. Res. Lett., 38(3), 2-6, doi:10.1029/2010GL046179, 2011.

Morelock, J., Schneidermann, N., and Bryant, W. R.: Shelf reefs, southwestern Puerto Rico, Stud. Geol., 4, 17$25,1977$.

Morelock, J., Ramirez, W. R., Bruckner, A. W., and Carlo, M.: Status of coral reefs, southwest Puerto Rico, Caribb. J. Sci. Spec. Publ., 4, 1-57, 2001.

Morse, J. W. and Arvidson, R. S.: The dissolution kinetics of major sedimentary carbonate minerals, EarthScience Rev., 58(1-2), 51-84, doi:10.1016/S0012-8252(01)00083-6, 2002.

Morse, J. W., Arvidson, R. S. and Lüttge, A.: Calcium carbonate formation and dissolution, Chem. Rev., doi:10.1021/cr050358j, 2007.

Morse, J. W., and Mackenzie, F. T.: Geochemistry of Sedimentary Carbonates, Elsevier B.V., 1990.

Moyer, R. P., Viehman, T. S., Piniak, G. A., and Gledhill, D. K.: Linking seasonal changes in benthic community structure to seawater chemistry, In Proceedings, 12th International Coral Reef Symposium. Cairns, Australia, 2012.

Mucci, A.: The solubility of Calcite and Aragonite in Seawater at various Salinities, Temperatures, and one Atmosphere Total Pressure, Am. J. Sci., 283, 780-799, 1983.

Muehllehner, N., Langdon, C., Venti, A., and Kadko, D.: Dynamics of carbonate chemistry, production, and calcification of the Florida Reef Tract (2009-2010): Evidence for seasonal dissolution, Global Biogeochemical Cycles, 30, 661-688, doi:10.1002/2015GB005327, 2016.

Ohde, S., and Hossain, M. M. M.: Effect of $\mathrm{CaCO}_{3}$ (aragonite) saturation state of seawater on calcification of Porites coral, Geochemical Journal, 38(6), 613-621, 2004.

Otero, E. and Carbery, K. K.: Chlorophyll a and turbidity patterns over coral reefs systems of La Parguera Natural Reserve, Puerto Rico, Rev. Biol. Trop., 53(SUPPL. 1), 25-32, 2005.

Page, H. N., Courtney, T. A., Collins, A., De Carlo, E. H., and Andersson, A. J.: Net Community Metabolism and Seawater Carbonate Chemistry Scale Non-intuitively with Coral Cover, Front. Mar. Sci., doi:10.3389/fmars.2017.00161, 2017.

Perry, C. T., Steneck, R. S., Murphy, G. N., Kench, P. S., Edinger, E. N., Smithers, S. G., and Mumby, P. J., Regional-scale dominance of non-framework building corals on Caribbean reefs affects carbonate production and future reef growth. Global change biology, 21(3),1153-1164, 2015. 
Biogeosciences Discuss., https://doi.org/10.5194/bg-2018-408

Manuscript under review for journal Biogeosciences

Discussion started: 12 October 2018

(c) Author(s) 2018. CC BY 4.0 License.

Perry, C. T., Murphy, G. N., Kench, P. S., Smithers, S. G., Edinger, E. N., Steneck, R. S., and Mumby, P. J.: Caribbean-wide decline in carbonate production threatens coral reef growth, Nat. Commun., 4, 1402, doi:10.1038/ncomms2409, 2013.

Perry, C. T., Alvarez-Filip, L., Graham, N. A. J., Mumby, P. J., Wilson, S. K., Kench, P. S., Manzello, D. P., Morgan, K. M., Slangen, A. B. A., Thomson, D. P., Januchowski-Hartley, F., Smithers, S. G., Steneck, R. S., Carlton, R., Edinger, E. N., Enochs, I. C., Estrada-Saldívar, N., Haywood, M. D. E., Kolodziej, G., Murphy, G. N., Pérez-Cervantes, E., Suchley, A., Valentino, L., Boenish, R., Wilson, M. and Macdonald, C.: Loss of coral reef growth capacity to track future increases in sea level, Nature, 558(7710), 396-400, doi:10.1038/s41586-0180194-z, 2018.

Pittman, S. J., Hile, S. D., Jeffrey, C. F. G., Clark, R., Woody, K., Herlach, B. D., Caldow, C., Monaco, M., and Appeldoorn, R. S.: Coral reef ecosystems of Reserva Natural de La Parguera (Puerto Rico): Spatial and temporal patterns in fish and benthic communities (2001-2007), NOAA Tech. Mem. NOS NCCOS 107, 202, 2010.

Plummer, L. N., Wigley, T. M. L., and Parkhurst D. L.: The kinetics of calcite dissolution in CO2-water systems at 5 to $60{ }^{\circ} \mathrm{C}$ and 0.0 to $1.0 \mathrm{~atm}$ CO2. Amer. Jour. Sci. 278, 179-216, 1978.

Revelle, R., and Suess, H. E.: Carbon dioxide exchange between atmosphere and ocean and the question of an increase of atmospheric $\mathrm{CO}_{2}$ during the past decades, Tellus, 9, 18-27, 1957.

Ricke, K. L., Orr, J. C., Schneider, K., and Caldeira, K.: Ricks to coral reefs from ocean carbonate chemistry changes in recent earth system model projections, Environ. Res. Lett., 8, 1-6, doi:10.1088/17489326/8/3/034003, 2013.

Riebesell, U., Zondervan, I., Rost, B., Tortell, P. D., Zeebe, R. E., and Morel, F. M.: Reduced calcification of marine plankton in response to increased atmospheric $\mathrm{CO}_{2}$, Nature, 407(6802), 364-7, doi:10.1038/35030078, 2000.

Ryan, K. E., Walsh, J. P., Corbett, D. R., and Winter, A.: A record of recent change in terrestrial sedimentation in a coral-reef environment, La Parguera, Puerto Rico: A response to coastal development?, Mar. Pollut. Bull., doi:10.1016/j.marpolbul.2008.02.017, 2008.

Sabine, C. L., Feely, R. A., Gruber, N., Key, R. M., Lee, K., Bullister, J. L., Wanninkhof, R., Wong, C. S., Wallace, D. W. R., Tilbrook, B., Millero, F. J., Peng, T.-H., Kozyr, A., Ono, T., and Rios, A. F.: The oceanic sink for anthropogenic $\mathrm{CO}_{2}$, Science, 305(5682), 367-71, doi:10.1126/science.1097403, 2004.

Shadwick, E. H., Thomas, H., Azetsu-Scott, K., Greenan, B. J. W., Head, E., and Horne, E.: Seasonal variability of dissolved inorganic carbon and surface water $\mathrm{pCO}_{2}$ in the Scotian Shelf region of the Northwestern Atlantic, Mar. Chem., 124, 23-37, doi:10.1016/j.marchem.2010.11.004, 2011.

Shamberger, K. E. F., Feely, R. A., Sabine, C. L., Atkinson, M. J., DeCarlo, E. H., Mackenzie, F. T., Drupp, P. 180 
Biogeosciences Discuss., https://doi.org/10.5194/bg-2018-408

Manuscript under review for journal Biogeosciences

Discussion started: 12 October 2018

(c) Author(s) 2018. CC BY 4.0 License.

Silbiger, N. J., Guadayol, Ò., Thomas, F. I. M., and Donahue, M. J.: Reefs shift from net accretion to net erosion along a natural environmental gradient, Mar. Ecol. Prog. Ser., 515, 33-44, doi:10.3354/meps 10999, 2014.

Silverman, J., Lazar, B., and Erez, J.: Effect of aragonite saturation, temperature, and nutrients on the community calcification rate of a coral reef, J. Geophys. Res.-Oceans, 112, doi:10.1029/2006JC003770, 2007.

Smith, S. V., and Jokiel, P. L.: Water composition and biogeochemical gradients in the Canton Atoll lagoon. Atoll Res. Bull., 221,15-53,1978.

Stearn, C. W., Scoffin, T. P., and Martinade, W.: Calcium carbonate budget of a fringing reef on the west coast of Barbados Part 1 - zonation and productivity, J. Mar. Sci., 27, 479-510, 1977.

Strickland, J. D., and Parsons, T. R.: A practical handbook of seawater analysis, 1972.

Sutton, A. J., Sabine, C. L., Maenner-Jones, S., Lawrence-Slavas, N., Meinig, C., Feely, R. A., Mathis, J. T., Musielewicz, S., Bott, R., McLain, P. D., Fought, H. J., and Kozyr, A.: CDIAC data management and archival support for a high-frequency atmospheric and seawater $\mathrm{pCO}_{2}$ data set from 14 open ocean moorings, Earth Syst. Sci. Data, 6, 353-366, doi:10.3334/CDIAC/OTG.TSM, 2014a.

Sutton, A. J., Sabine, C. L., Morell, J. M., Musielewicz, S., Maenner, S., Dietrich, C., Bott, R., Osborne, J.: Highresolution ocean and atmosphere $\mathrm{pCO}_{2}$ time-series measurements from mooring La_Parguera_67W_18N in the Caribbean Sea: NODC Accession 0117354. Version 5.5. National Oceanographic Data Center, NOÄA. Dataset. doi:10.3334/CDIAC/OTG.TSM_LA_PARGUERA_67W_18N, 2014b.

Takahashi, T., Olafsson, J., Goddard, J. G., Chipman, D. W., and Sutherland, S. C.: Seasonal variation of $\mathrm{CO}_{2}$ and nutrients in the high-latitude surface oceans: A comparative study. Global Biogeochemical Cycles, 7(4), 843$878,1993$.

Takeshita, Y., McGillis, W., Briggs, E. M., Carter, A. L., Donham, E. M., Martz, T. R., Price, N. N., and Smith, J. E.: Journal of Geophysical Research: Oceans coral reef using a boundary layer approach, 5655-5671, doi:10.1002/2016JC011886, 2016.

Teneva, L., Dunbar, R. B., Mucciarone, D. A., Dunckley, J. F., and Koseff, J. R.: High-resolution carbon budgets on a Palau back-reef modulated by interactions between hydrodynamics and reef metabolism, Limnol. Oceanogr., 58, doi:10.4319/1o.2013.58.5.1851, 2013.

Turk, D., Yates, K. K., Vega-Rodriguez, M., Toro-Farmer, G., L’Esperance, C., Melo, N., Ramsewak, D., Dowd, M., Estrada, S. C., Muller-Karger, F. E., Herwitz, S. R., and McGillis, W. R.: Community metabolism in shallow coral reef and seagrass ecosystems, lower Florida Keys, Mar. Ecol. Prog. Ser., 538, 35-52, doi:10.3354/meps11385, 2015.

van Heuven, S., Pierrot, D., Rae, J.W.B., Lewis, E., and Wallace, D.W.R.: MATLAB Program Developed for CO2 System Calculations. ORNL/CDIAC-105b. Carbon Dioxide Information Analysis Center, Oak Ridge National Laboratory, U.S. Department of Energy, Oak Ridge, Tennessee. doi:

10.3334/CDIAC/otg.CO2SYS_MATLAB_v1.1, 2011. 
Biogeosciences Discuss., https://doi.org/10.5194/bg-2018-408

Manuscript under review for journal Biogeosciences

Discussion started: 12 October 2018

(c) Author(s) 2018. CC BY 4.0 License.

Venti, A., Andersson, A., and Langdon, C.: Multiple driving factors explain spatial and temporal variability in coral calcification rates on the Bermuda platform, Coral Reefs, 979-997, doi:10.1007/s00338-014-1191-9, 2014.

Venti, A., Kadko, D., Andersson, A.J., Langdon, C., and Bates, N. R.: A multi-tracer model approach to estimate reef water residence times. Limnology and Oceanography: Methods, 10(12),1078-1095, 2012.

Wanninkhof, R.: Relationship between wind speed and gas exchange over the ocean revisited, Limnol. Oceanogr. Methods, 12(6), 351-362, doi:10.4319/1om.2014.12.351, 2014.

Winkler, L.S.: The determination of dissolved oxygen. Ber. Dtsche. Chern. Ges., 21, 2843-2855, 1888

Weiss, R. F.: Carbon dioxide in water and seawater: the solubility of a non-ideal gas, Mar. Chem., 2, 203-215, 1974.

Xue, L., Cai, W. J., Hu, X., Sabine, C., Jones, S., Sutton, A. J., Jiang, L. Q., and Reimer, J. J.: Sea surface carbon dioxide at the Georgia time series site (2006-2007): Air-sea flux and controlling processes, Prog. Oceanogr., 140, 14-26, doi:10.1016/j.pocean.2015.09.008, 2016.

Yates, K. K., and Halley, R. B.: $\mathrm{CO}_{3}{ }^{2-}$ concentration and $\mathrm{pCO}_{2}$ thresholds for calcification and dissolution on the Molokai reef flat, Hawaii, Biogeosciences, 3(3), 357-369, 2006.

Yates, K. K., Halley, R. B., and Moomaw, A.: The Submersible Habitat for Analyzing Reef Quality (SHARQ): Improved technology for benthic analyses and experimentation, 28-30, 1999.

Yeakel, K. L., Andersson, A. J., Bates, N. R., Noyes, T. J., Collins, A., and Garley, R.: Shifts in coral reef biogeochemistry and resulting acidification linked to offshore productivity, Proc. Natl. Acad. Sci., 112(47), 14512-14517, doi:10.1073/pnas.1507021112, 2015.

Zayas-Santiago, C. C.: Landscape structure in two reefs in La Parguera and the distribution of the Lytechinus variegatus, University of Puerto Rico, Mayaguez Campus, 2011.

Zeebe, R. E., and Wolf-Gladrow, D. A.: CO2 in seawater: equilibrium, kinetics, isotopes, Gulf Professional Publishing, 65, 2001. 
Biogeosciences Discuss., https://doi.org/10.5194/bg-2018-408

Manuscript under review for journal Biogeosciences

Discussion started: 12 October 2018

(C) Author(s) 2018. CC BY 4.0 License.

(c) (i)

Table 1: $\mathrm{MapCO}_{2}$ observations and model uncertainties.

\begin{tabular}{|c|c|c|}
\hline Buoy Observations & Error \pm & Method \\
\hline Temperature $\left({ }^{\circ} \mathrm{C}\right)$ & \pm 0.01 & Sutton et al. (2014a) \\
\hline Salinity (SSS) & \pm 0.05 & Sutton et al. (2014a) \\
\hline$p \mathrm{CO}_{2 \mathrm{sw}}(\mu \mathrm{atm})$ & $\pm<2$ & Sutton et al. (2014a) \\
\hline $\mathrm{O}_{2}$ & $\pm 3 \%$ & See Section 2.3 \\
\hline \multicolumn{3}{|l|}{ Model parameter } \\
\hline $\mathrm{TA}_{\text {reef }}\left(\mu \mathrm{mol} \mathrm{kg}{ }^{-1}\right)$ & \pm 16 & Monte Carlo \\
\hline $\operatorname{DIC}_{\text {reef }}\left(\mu \mathrm{mol} \mathrm{kg}{ }^{-1}\right)$ & \pm 12 & Monte Carlo \\
\hline$\Omega_{\text {arag }}$ & \pm 0.12 & Monte Carlo \\
\hline $\mathrm{CO}_{2}$ Flux $\left(\mathrm{mmol} \mathrm{m}^{-2}\right.$ day $\left.^{-1}\right)$ & \pm 0.72 & Sum of the squares \\
\hline $\mathrm{O}_{2}$ Flux $\left(\mathrm{mmol} \mathrm{m}{ }^{-2}\right.$ day $\left.^{-1}\right)$ & \pm 2.04 & Monte Carlo \\
\hline DICAIR-SEA EX $\left(\mu \mathrm{mol} \mathrm{kg}^{-1}\right)$ & \pm 0.24 & Monte Carlo \\
\hline DICвіо $\left(\mathrm{mmol} \mathrm{m}^{-2}\right)$ & \pm 0.3 & Monte Carlo \\
\hline Revelle Factor & \pm 0.66 & Monte Carlo \\
\hline$\partial \mathrm{pCO}_{2, \mathrm{OBS}}(\mu \mathrm{atm})$ & \pm 1.1 & Monte Carlo \\
\hline$\partial \mathrm{pCO}_{2, \mathrm{SoL}}(\mu \mathrm{atm})$ & \pm 0.3 & Monte Carlo \\
\hline$\partial \mathrm{pCO}$,AIR-SEA EX $(\mu \mathrm{atm})$ & \pm 0.1 & Monte Carlo \\
\hline$\partial \mathrm{pCO}_{2, \mathrm{HOR} \text { MIX }}(\mu \mathrm{atm})$ & \pm 0.5 & Gradient observations* \\
\hline$\partial \mathrm{pCO}_{2, \mathrm{BIO}}(\mu \mathrm{atm})$ & \pm 1.2 & Monte Carlo \\
\hline $\operatorname{NEP}\left(\mathrm{mmol} \mathrm{C} \mathrm{m} \mathrm{m}^{-2} \mathrm{day}^{-1}\right)$ & \pm 2.08 & Monte Carlo \\
\hline $\mathrm{NEC}\left(\mathrm{mmol} \mathrm{CaCO}_{3} \mathrm{~m}^{-2} \mathrm{day}^{-1}\right)$ & \pm 2.18 & Monte Carlo \\
\hline
\end{tabular}

*refer to Sect. 2.6.2 for details 
Biogeosciences Discuss., https://doi.org/10.5194/bg-2018-408

Manuscript under review for journal Biogeosciences

Discussion started: 12 October 2018

(c) Author(s) 2018. CC BY 4.0 License.

(c) (1)

Table 2: Summary of the reef station seasonal variability of the carbonate and oceanography parameters from 2009 to 2017 . The ( \pm ) is the standard deviation.

\begin{tabular}{|c|c|c|c|c|}
\hline Parameter & Mean & Max & Min & Seasonal change \\
\hline Temperature $\left({ }^{\circ} \mathrm{C}\right)$ & $28.5 \pm 0.41$ & 30.2 & 26.6 & 3.62 \\
\hline Salinity & $35.3 \pm 0.26$ & 36.1 & 34.4 & 1.63 \\
\hline Wind speed $\left(\mathrm{m} \mathrm{s}^{-1}\right)$ & $4.21 \pm 1.76$ & 6.38 & 2.36 & 4.01 \\
\hline Residence Time (days) $^{*}$ & $15 \pm 3$ & $9 \pm 2($ Jan $)$ & $13 \pm 2$ (May) & 4 \\
\hline $\mathrm{DIC}\left(\mu \mathrm{mol} \mathrm{kg}{ }^{-1} \mathrm{sw}\right)$ & $1972 \pm 13.9$ & 2000 & 1931 & 69.3 \\
\hline $\mathrm{TA}\left(\mu \mathrm{mol} \mathrm{kg}{ }^{-1}{ }_{\mathrm{sw}}\right)$ & $2287 \pm 13.7$ & 2332 & 2231 & 101 \\
\hline Revelle Factor & $9.25 \pm 0.11$ & 9.49 & 9.06 & 0.43 \\
\hline$p \mathrm{CO}_{2, \mathrm{sw}}(\mu \mathrm{atm})$ & $423 \pm 13.5$ & 461 & 387 & 73.1 \\
\hline$p \mathrm{CO}_{2, \text { air }}(\mu \mathrm{atm})$ & $386 \pm 8.52$ & 391 & 378 & 12.6 \\
\hline$\Delta p \mathrm{CO}_{2, \text { sea-air }}(\mu \mathrm{atm})$ & $38.2 \pm 14.2$ & 80.8 & 0.72 & 80.1 \\
\hline pH (total scale) & $8.02 \pm 0.01$ & 8.06 & 7.98 & 0.07 \\
\hline$\Omega_{\text {arag }}$ & $3.59 \pm 0.07$ & 3.76 & 3.4 & 0.36 \\
\hline $\mathrm{O}_{2}\left(\mu \mathrm{mol} \mathrm{kg}{ }^{-1}\right)$ & $176 \pm 10.6$ & 192 & 154 & 37.8 \\
\hline $\mathrm{F}_{\mathrm{CO} 2}\left(\mathrm{mmol} \mathrm{m}{ }^{-2} \mathrm{day}^{-1}\right)$ & $2.04 \pm 2.13$ & 6.78 & 0.11 & 6.67 \\
\hline $\mathrm{F}_{\mathrm{O} 2}\left(\mathrm{mmol} \mathrm{m}^{-2}\right.$ day $\left.^{-1}\right)$ & $-23.3 \pm 22.5$ & 14.2 & -86.6 & 72.4 \\
\hline $\operatorname{NEC}\left(\mathrm{mmol} \mathrm{m}{ }^{-2}\right.$ day $\left.^{-1}\right)$ & $-18.1 \pm 2.1$ & 12.0 & -57.7 & 45.7 \\
\hline $\mathrm{NEP}\left(\mathrm{mmol} \mathrm{m}{ }^{-2} \mathrm{day}^{-1}\right)$ & $17.9 \pm 2.2$ & 66.8 & -10.9 & 55.9 \\
\hline
\end{tabular}

$281{ }^{*}$ Reef water residence time relative to the offshore station located $\sim 11 \mathrm{~km}$ from Enrique reef (for details, see Sect. 2.2).

Table 3: Annual median Gibbs Free Energy $\left(\triangle \mathrm{G}\right.$, cal $\left.\mathrm{mol}^{-1} \mathrm{CaCO}_{3}\right)$ for a range of $\mathrm{CaCO}_{3}$ mineral phases under ambient conditions within the waters overlying Enrique reef.

\begin{tabular}{|c|c|c|c|c|c|c|c|}
\hline & Aragonite & Calcite & $\begin{array}{c}5 \% \\
\mathrm{MgCO}_{3}\end{array}$ & $\begin{array}{c}10 \% \\
\mathrm{MgCO}_{3}\end{array}$ & $\begin{array}{c}13 \% \\
\mathrm{MgCO}_{3}\end{array}$ & $\begin{array}{c}25 \% \\
\mathrm{MgCO}_{3}\end{array}$ & $\begin{array}{c}30 \% \\
\mathrm{MgCO}_{3}\end{array}$ \\
\hline $\begin{array}{c}\Delta \mathrm{G} \\
\left(\mathrm{cal} \mathrm{mol}^{-1} \mathrm{CaCO}_{3}\right)\end{array}$ & 754 & 1002 & 858 & 775 & 699 & 199 & -104 \\
\hline
\end{tabular}


Biogeosciences Discuss., https://doi.org/10.5194/bg-2018-408

Manuscript under review for journal Biogeosciences

Discussion started: 12 October 2018

(c) Author(s) 2018. CC BY 4.0 License.

(c) (1)
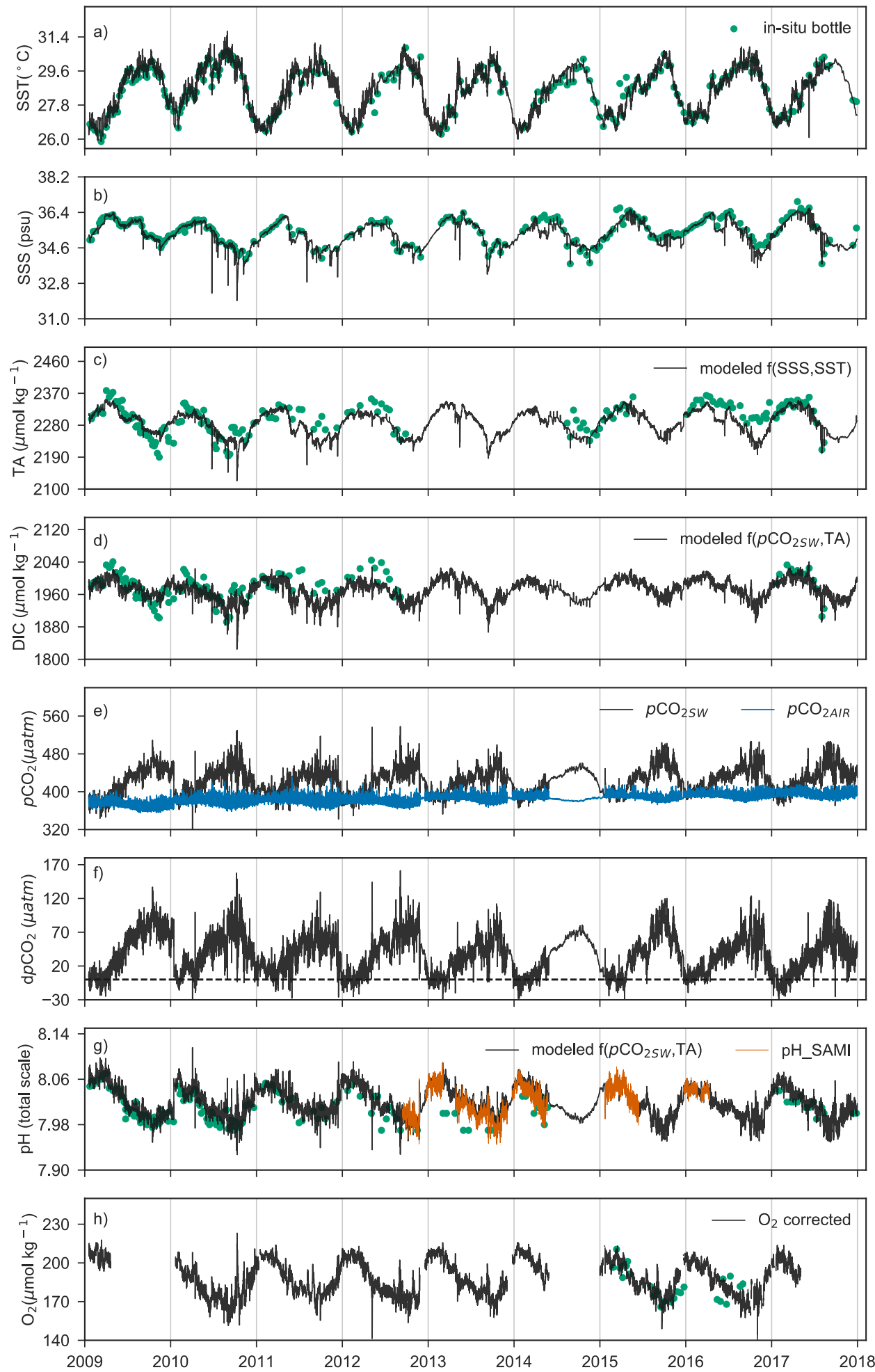
Biogeosciences Discuss., https://doi.org/10.5194/bg-2018-408

Manuscript under review for journal Biogeosciences

Discussion started: 12 October 2018

(c) Author(s) 2018. CC BY 4.0 License.

Figure 1: Multi-annual time series of the $\mathrm{MapCO}_{2}$ buoy (black line) and in situ (green dots) geochemical measurements, and derived values from 2009 to 2017 at the forereef of Enrique reef. Final measurements used for the analyses cover from January 2009 to January 2017. The data from Feb 2017 to December 2017 is preliminary see: www.pmel.noaa.gov/co2/story/La+Parguera. Sea surface observations of: a) temperature $\left(\mathrm{Temp} ;{ }^{0} \mathrm{C}\right)$, b) salinity (Sal), c) Derived total alkalinity $\left(\mathrm{TA} ; \mu \mathrm{mol} \mathrm{kg}^{-1}\right)$ as a function of SST and SSS (Eq.5), d) dissolved inorganic carbon (DIC; $\mu \mathrm{mol} \mathrm{kg}^{-1}$ ) as a function of $p \mathrm{CO}_{2}$ and TA, e) seawater and boundary layer atmospheric $p \mathrm{CO}_{2}\left(p \mathrm{CO}_{2, \mathrm{sw}}, p \mathrm{CO}_{2, \text { arr }} ; \mu \mathrm{atm}\right)$, f) air-sea gradient in $p \mathrm{CO}_{2}\left(\Delta p \mathrm{CO}_{2} ; \mu \mathrm{atm}\right)$, g) Derived pH as a function of $p \mathrm{CO}_{2}$ and TA and pH measurements from the SAMI-pH system (orange line), and h) Derived oxygen using the MAX-250+ sensor $\left(\mathrm{O}_{2}\right.$;
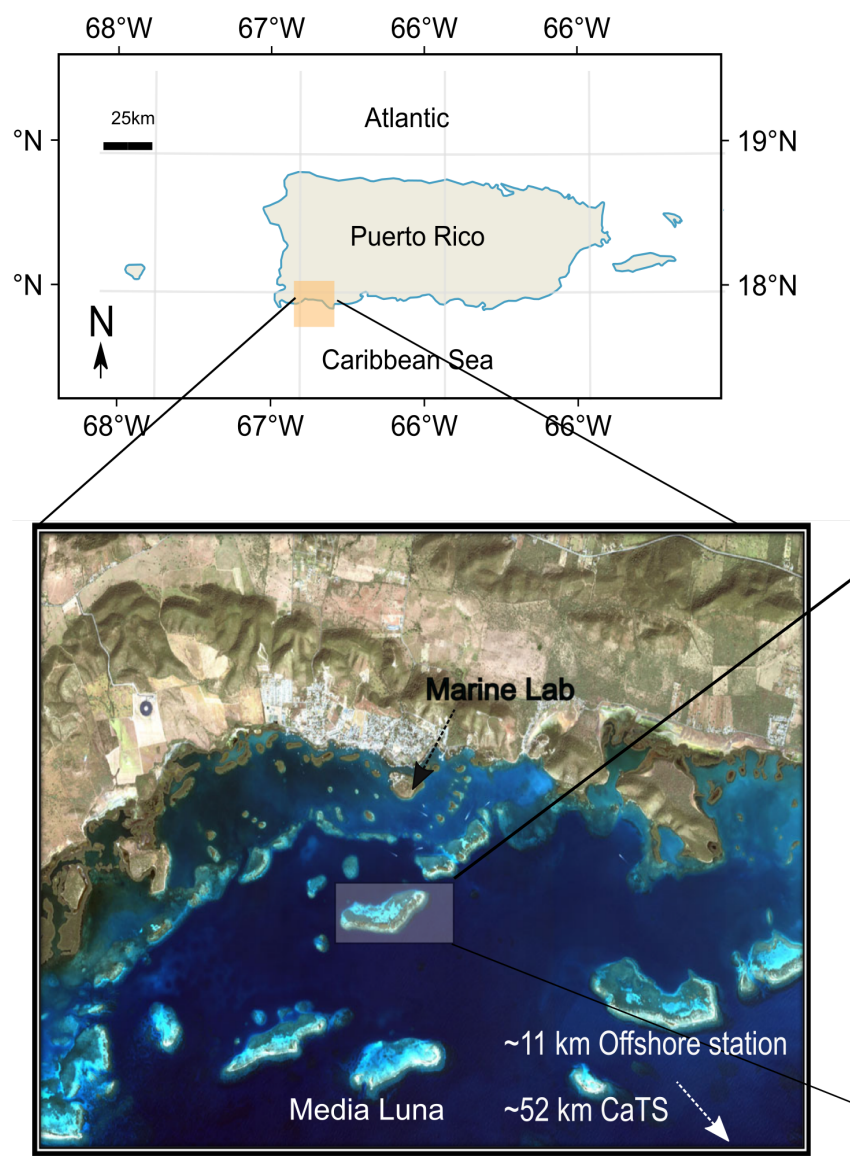

\section{Enrique reef}
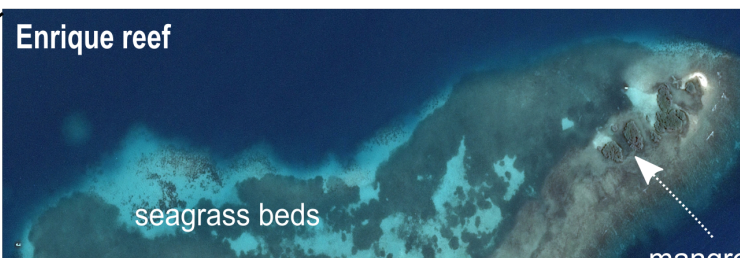

Figure 2: a) Map showing the town of Lajas $\left(18.05^{\circ} \mathrm{N}, 67.05^{\circ} \mathrm{W}\right)$ and the Marine Protected Area of La Parguera located on the southwest coast of Puerto Rico (orange box). b) The offshore sample stations (white dashed line) include the offshore station (17.87 $\mathrm{N},-\mathbf{- 6 7 . 0 2} \mathrm{W}$ ) located $\sim 11 \mathrm{~km}$ from Enrique reef and $1.6 \mathrm{~km}$ south (seaward) of the shelf-edge, and the Caribbean Time Series station (CaTS, $17.36{ }^{\circ} \mathrm{N}, 67^{\circ} \mathrm{W}$ ) at $\sim 52 \mathrm{~km}$ offshore. c) The $\mathrm{MapCO}_{2}$ buoy $\left(17.95^{\circ} \mathrm{N}, 67.05^{\circ} \mathrm{W}\right)$ is located at the west-end of Enrique (yellow dot) and over the forereef where the water depth is $\sim 3 \mathbf{m}$. Red mangroves have colonized the emergent reef island comprised by coral rubble. The dominant ocean current direction at the sea surface is towards the north-west. 
Biogeosciences Discuss., https://doi.org/10.5194/bg-2018-408

Manuscript under review for journal Biogeosciences

Discussion started: 12 October 2018

(c) Author(s) 2018. CC BY 4.0 License.

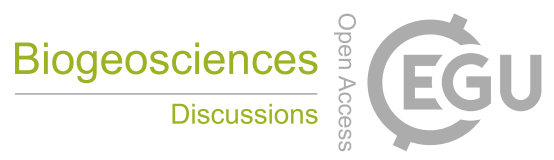

(c) (i)

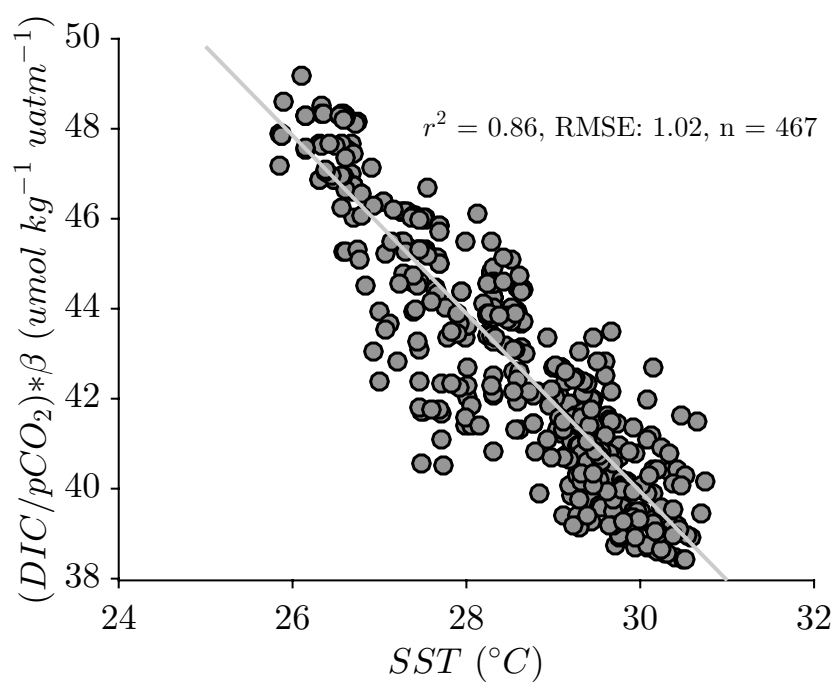

309 Figure 3: Linear relationship between the fractional DIC $\left(\mu \mathrm{mol} \mathrm{kg}^{-1}\right)$ and $p \mathrm{CO}_{2, \mathrm{sw}}\left(\mu \mathrm{atm}^{-1}\right)$ to Revelle Factor $(\beta)$ and SST $\left({ }^{\circ} \mathrm{C}\right)$. This 310 linear relationship $(\mathrm{y}=\mathrm{SST} \times \mathbf{- 2 . 0 2}( \pm \mathbf{0 . 0 0 2})+\mathbf{1 0 0}( \pm \mathbf{0 . 0 6 3}))$ was used to compute $\partial \mathrm{DIC} \mathrm{B}_{\mathrm{BIO}}$ from $\partial p \mathrm{CO}_{2 \mathrm{BIO}}$ according to equation 31111. 
Biogeosciences Discuss., https://doi.org/10.5194/bg-2018-408

Manuscript under review for journal Biogeosciences

Discussion started: 12 October 2018

(c) Author(s) 2018. CC BY 4.0 License.
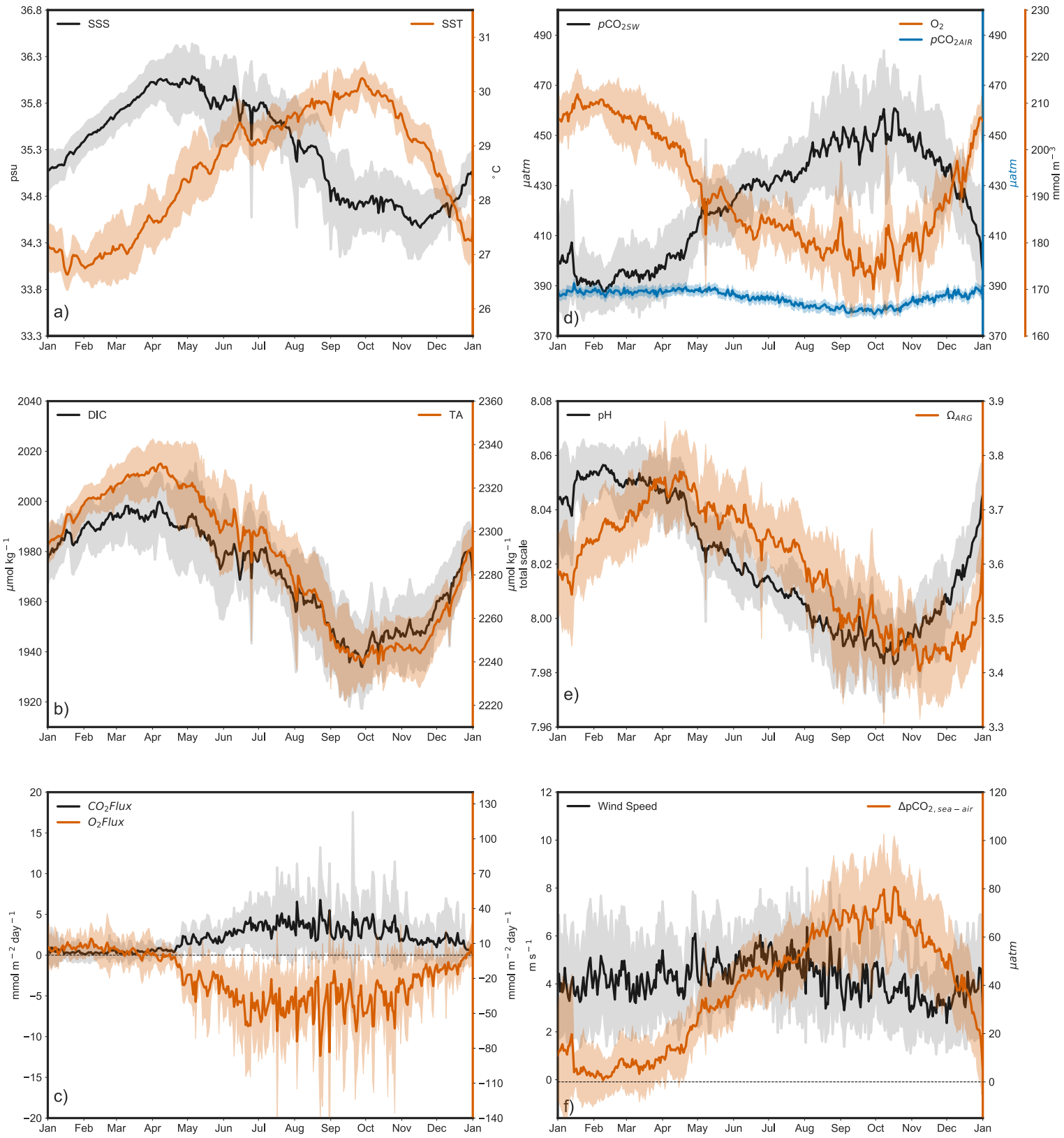

313 Figure 4: Seasonal series of the buoy measurements, hydrographic properties (e.g., wind speed, fluxes) and derived carbonate

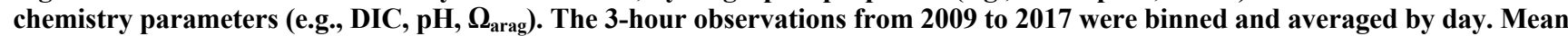
(solid line) and standard deviation (shaded bounds) demonstrate the seasonality of sea surface a) temperature (Temp; ${ }^{0} \mathrm{C}$; orange) and salinity (Sal; black), b) total alkalinity (TA; $\mu \mathrm{mol} \mathrm{kg}{ }^{-1}$; orange) and dissolved inorganic carbon (DIC; $\left.\left.\mu \mathrm{mol} \mathrm{kg} \mathrm{kg}^{-1} ; \mathrm{black}\right), \mathrm{c}\right) \mathrm{CO}_{2}$

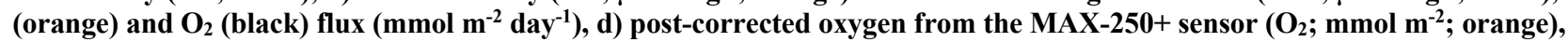
seawater (black) and air (blue) $p \mathrm{CO}_{2}\left(p \mathrm{CO}_{2, \mathrm{sw}}, p \mathrm{CO}_{2, \text { air }} ; \mu \mathrm{atm}\right)$, e) $\Omega_{\mathrm{ARG}}$ (orange) and pH (black) and f) air-sea gradient in $p \mathrm{CO}$ $\left(\triangle p \mathrm{CO}_{2} ; \mu \mathrm{atm}\right.$; orange) and wind speed $\left(\mathrm{m} \mathrm{s}^{-1} ;\right.$ black $)$. 
Biogeosciences Discuss., https://doi.org/10.5194/bg-2018-408

Manuscript under review for journal Biogeosciences

Discussion started: 12 October 2018

(c) Author(s) 2018. CC BY 4.0 License.

(c) (i)

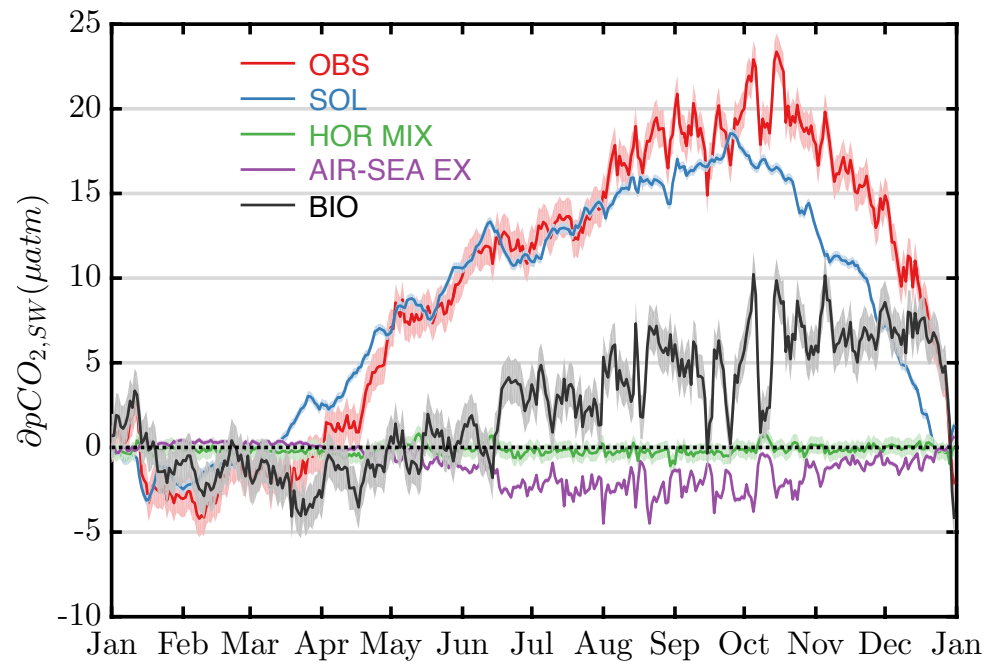

Figure 5: Cumulative seasonal change in surface $p \mathrm{CO}_{2, \mathrm{sw}}\left(\mathrm{ppCO}_{2, \mathrm{sw}} ; \mu \mathrm{atm}\right)$ are based on contributions from thermodynamic, physical, and biological processes at Enrique forereef. The average (solid line) is determined from 2009 to 2017 data, with model uncertainties (shaded bounds, Table 1). Observed $p \mathrm{CO}_{2}$ values (OBS; red), effects of temperature and salinity variability (SOL; blue), effects of horizontal mixing (HOR MIX; green), effects of air-sea exchange (AIR-SEA EX; purple) and effects of biological activity (BIO; black).

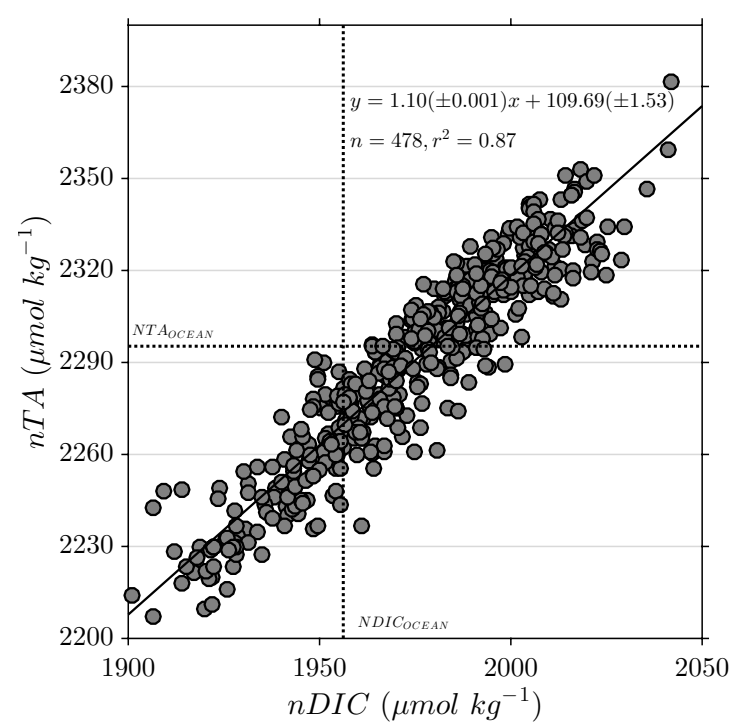

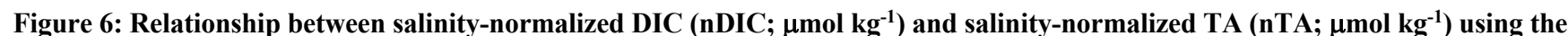
in situ bottle measurements collected at the $\mathrm{MapCO}_{2}$ buoy from 2009 to 2017. DIC and TA measurements were normalized by the mean oceanic salinity $(S=36.0)$ to correct for the influence of freshwater addition and removal; and explore the biological processes that also influence TA and DIC. 
Biogeosciences Discuss., https://doi.org/10.5194/bg-2018-408

Manuscript under review for journal Biogeosciences

Discussion started: 12 October 2018

(c) Author(s) 2018. CC BY 4.0 License.

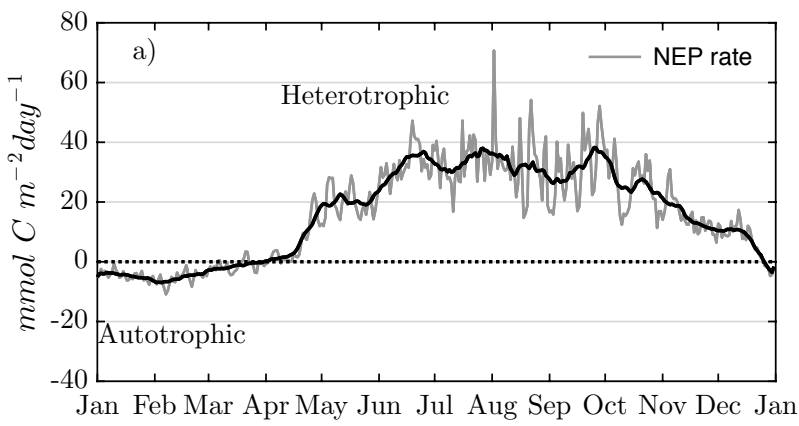

Figure 7: Annual composites based on daily averages of modeled a) NEP (mmol C m ${ }^{-2} \mathrm{day}^{-1}$; gray line) and b) NEC rates (mmol $\mathrm{CaCO}_{3} \mathrm{~m}^{-2} \mathrm{day}^{-1}$; gray line). Solid black line is a moving average of span 15 . NEP $>0$ are representative of net heterotrophic and NEP $<0$ indicate net autotrophic. NEC $>0$ indicates net calcification and NEC $<0$ net dissolution.
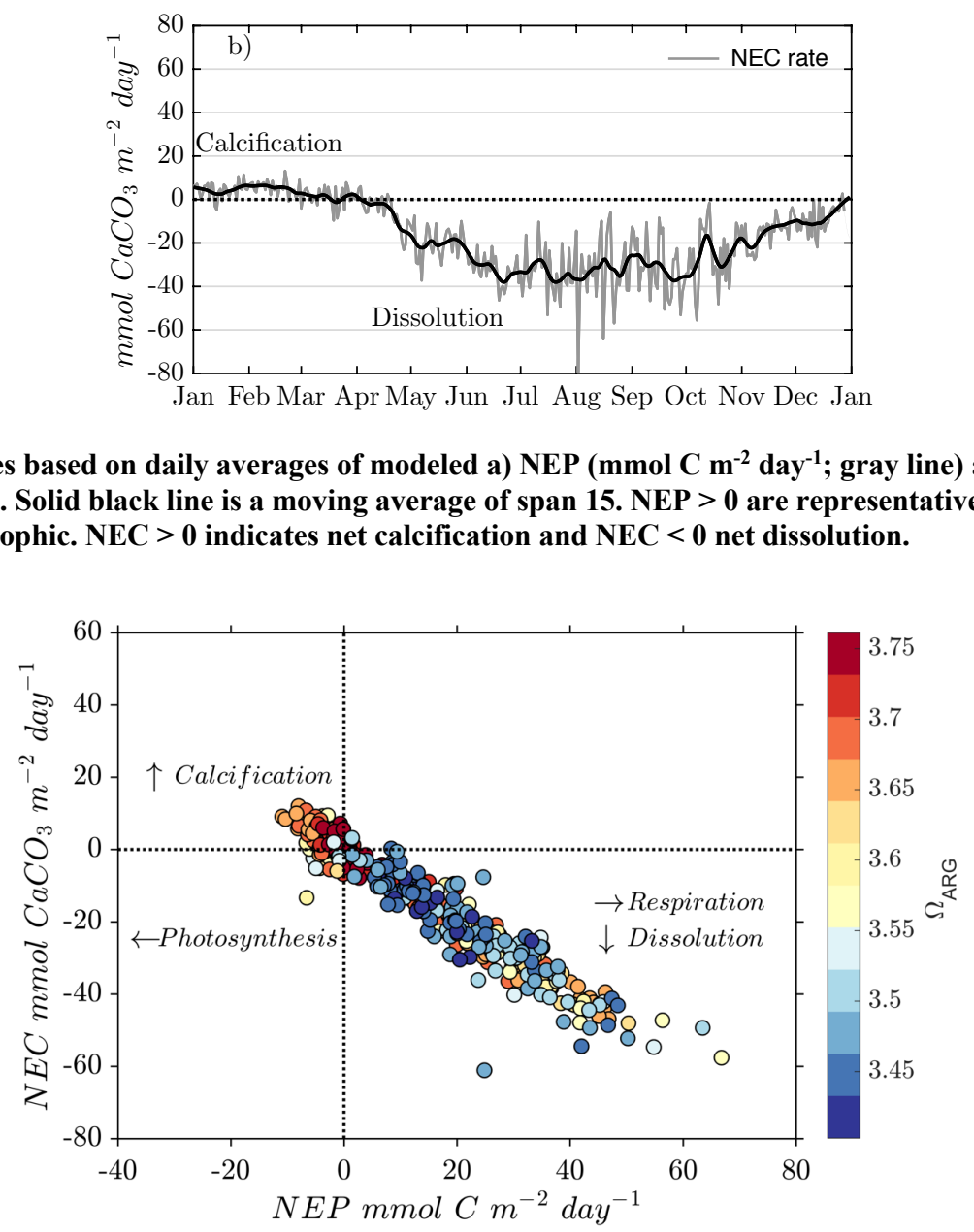

337 Figure 8: $\mathrm{NEC}\left(\mathrm{mmol} \mathrm{CaCO}_{3} \mathrm{~m}^{-2}\right.$ day $\left.^{-1}\right)$ versus NEP rates $\left(\mathrm{mmol} \mathrm{C} \mathrm{m}^{-2}\right.$ day $\left.^{-1}\right)$ in relationship with $\Omega_{\text {arag }}$ indicated with colorbars. 338 The zero line of NEC and NEP are denoted by grey dashed lines. 
Biogeosciences Discuss., https://doi.org/10.5194/bg-2018-408

Manuscript under review for journal Biogeosciences

Discussion started: 12 October 2018

(c) Author(s) 2018. CC BY 4.0 License.

(c) (i)
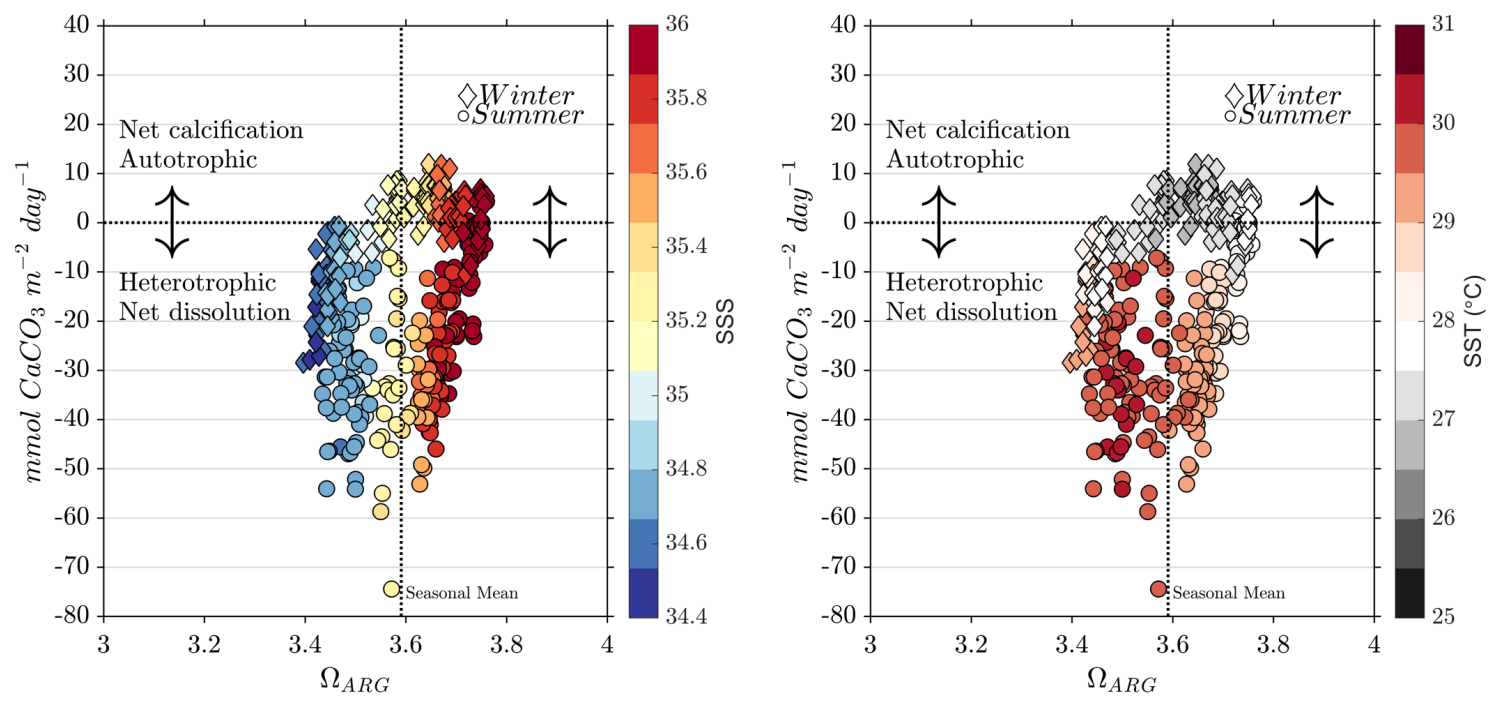

Figure 9: Seasonal hysteresis of $\mathrm{NEC}\left(\mathrm{mmol} \mathrm{CaCO}_{3} \mathrm{~m}^{-2}\right.$ day $\left.^{-1}\right)$ relative to $\Omega_{\text {arag }}$ and colored by (a) SSS and (b) SST $\left({ }^{\circ} \mathrm{C}\right)$ indicated with colorbars. The diamond symbols represent the winter values and the circle symbols the summer. The zero line of $\mathrm{NEC}$ and the seasonal mean of $\Omega_{\text {arag }}$ are denoted by grey dashed lines.

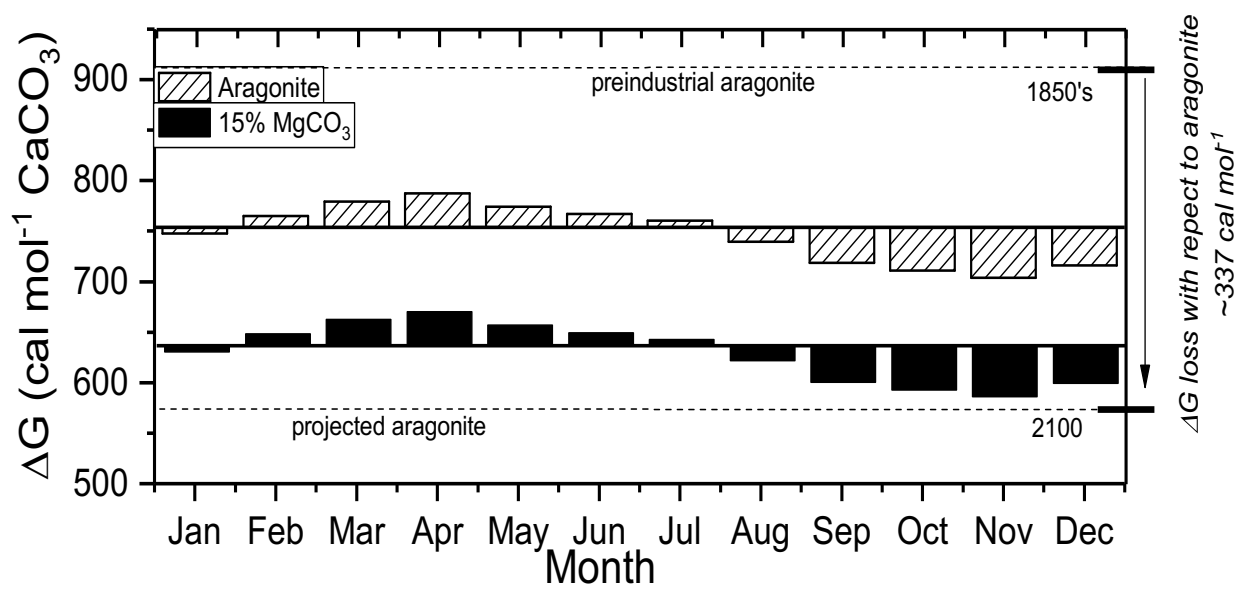

345 Figure 10: Seasonal dynamics in free energy (cal mol-1 CaCO3) at Enrique reef for Aragonite (dashed) and 15\% MgCO3 (solid black). The dashed lines represent the free energy for aragonite in the 1850 and the projection for 2100. 